\title{
Failure to Protect a Natural Site: Istanbul Tuzla Kamil Abdus Lake
}

\author{
Gokce Gulcem Duman \\ Tuzla Municipality, Departmant of Planning and Project \\ Postane Mah. Yaliboyu Cad. No: 55-13 Tuzla, Istanbul, Turkey \\ E-mail: gokcegulcemgokhan@gmail.com \\ Elif Ornek Ozden \\ Yildiz Technical University \\ Depertmant of Urban and Regional Planning \\ Barbaros Bulvari, Yildiz, Besiktas, Istanbul, Turkey \\ E-mail: elifornek@gmail.com
}

\begin{abstract}
While the "protected area" status in areas that need to be protected should be a decision regarding protection, natural areas are rapidly destroyed and consumed due to the problems experienced. Kamil Abduş Lake and its surroundings, which are the only natural examples for Istanbul, although they have the status of a natural site, have been examined and suggestions have been made.

The main subject of the study is the examination of not being protected of a lagoon lake consisting of first and third degree natural protected areas and which should be transferred to future generations due to this feature, The lake, which faces the danger of extinction as a result of the intervention of the central administration on the plan decisions as a result of neoliberal policies, the wrong interventions and the declaration of the natural site as renewal area, was analyzed analytically based on the plan decisions. It has been determined with which planning decisions and unconscious interventions that the lake and its surroundings have lost its characteristic of being the lagoon lake, and what interventions have been made in order to regain it and how the results of all of these have been reflected in the natural site. In the conclusion, suggestions have been developed on what can be done instead of wrongly defined interventions.
\end{abstract}

Keywords: Natural protected area, Urban conservation, Urban renewal, Regenerate, Sustainable conservation

DOI: $10.7176 / \mathrm{JSTR} / 6-05-02$

\section{Bir Doğal Sit Alanının Korunamaması: İstanbul Tuzla Kamil Abdus Gölü}

Özet

Korunması gerekli alanlarda "sit alanı" statüsü, korumaya yönelik bir karar olması gerekirken yaşanan sorunlar nedeni ile doğal alanlar hızla tahrip olmakta ve tüketilmektedir. İstanbul için tek örnek olan doğal sit statüsünde olduğu halde yenileme alanı da olan Kamil Abduş Gölü ve çevresi irdelenmiş ve önermelerde bulunulmuştur.

Çalışmanın temel konusu; bir bölümü birinci, bir bölümü üçüncü derece doğal sit alanı olan ve bu özelliği nedeni ile korunarak gelecek nesillere aktarılması gereken bir lagün gölünün korunamamasının irdelenmesidir. Gerek neoliberal politikalar sonucu merkezi idarenin plan kararları üzerine müdahalesi, gerekse yapılan yanlış müdahaleler ve gerekse doğal sit alanının yenileme alanı ilan edilmesi sonucu yok olma tehlikesi ile karşı karşıya kalan gölün plan kararları temel alınarak analitik olarak incelemesi yapılmıștır. Göl ve çevresinin, lagün gölü olma özelliğini hangi planlama kararları ve bilinçsiz müdahaleler ile kaybettiği tespit edilmiş, yeniden kazanılması amaciyla hangi müdahalelerde bulunulduğu ve tüm bunların sonuçlarının doğal sit alanına yansımaları ortaya konulmuştur. Sonuç bölümünde ise yanlış olarak tanımlanan müdahalelerin yerine neler yapılabileceği konusunda öneriler geliştirilmiştir.

Anahtar Kelimeler: Doğal koruma alanları, kentsel koruma, kentsel yenileme, yeniden canlandırma, sürdürülebilir koruma 


\section{Giriş}

Günümüzde çevre sorunları, ele alınan her konuya ‘sürdürülebilirlik' kavramı ile bakmayı zorunlu hale getirmiştir. Yaşanabilir bir çevre için sürdürülebilir gelişme kavramı, "doğal kaynakları tüketmeyen, gelecek kuşakların gereksinmelerini de karşılayabilmesine olanak sağlayacak şekilde, ekosistem ile ekonomi arasındaki dengeyi korumak” olarak tanımlanabilir. Çevre yasasında (2872 sayıl1, 2006 yılında yapılan değişiklik) 'sürdürülebilir çevre' ve 'sürdürülebilir kalkınma' kavramlarına değinilmiştir. Buna göre 'sürdürülebilir çevre', 'gelecek kuşakların gereksinme duyacağı kaynakların varlığını ve kalitesini tehlikeye atmadan hem bugünün, hem de gelecek kuşakların çevresini oluşturan tüm çevresel değerlerin her alanda iyileştirilmesi, korunması ve geliştirilmesi sürecidir.' Ülkemizde de sürdürülebilirlik hem uluslararası platformda kabul edilmiş hem de Çevre yasasında da olduğu gibi iç hukuka aktarılmaya çalışılmış olmasına rağmen, 20.yy da, biyolojik çeşitlilik ve doğal kaynaklar, sürdürülebilir olmayan gelişme yani çevresel ve sosyal bozulmalara yol açan insan faaliyetleri ve politikaları sonucu, insanlık tarihinde hiç görülmemiş bir oranda tahrip edilmektedir. İklim değişikliği, her türlü çevresel kirlenme ve doğal kaynakların sürdürülebilir olmayan kullanımı biyolojik çeşitlilikle beraber insanın refahını ve yaşamsal gereksinmelerini karşılamasını imkânsız hale getirmektedir. $\mathrm{Bu}$ çerçevede özellikle sürdürülebilirlik bağlamında, küreselleşmenin oluşturduğu ve dayattığı "yarışan kentler" kavramı, sürdürülemezliğin gerçekleşmesindeki en önemli etkenlerden birisini oluşturmaktadır. Yarışmayı kazananlar kimi ekonomik kazançlar sağlasalar da çevresel açıdan kaybettikleri gibi kentlerinin kimliklerini de kaybetmektedirler.

İstanbul içinde benzer sorunlardan bahsetmek mümkündür. "Dünyanın en büyük havalimanı", “dünyanın en uzun asma köprüsü” gibi söylemlerle prestiji artırılmaya çalışan büyük ölçekli kentsel projelere ev sahipliği yapan İstanbul, hem çevresel açıdan- doğal kaynakların tüketilmesi gibi-, hem de sosyal açıdan-kutuplaşma, kimliksizleşme, kentsel adaletsizlik gibi- 'Yarışan Kent', 'Dünya Kenti' söylemlerin olumsuz etkileri ile şekillenir hale gelmiştir. Çalışma bu bağlamda tüketilen bir doğal kaynağı araştırma konusu olarak belirlemiştir. Örnekleme alanı bir doğal sit alanıdır. Ülkemizde doğa koruma konusunda atılan en net adımlardan biri olan "sit alanı" statüsü, bu alanların korunması için gerekli ve yeterli temel karar olması gerekirken, korunan alanlarda yaşanan kurumsal yetki karmaşası, çok başl1lık ve mevcut mevzuattaki yasal boşluklar (yasal ve yönetsel sorunlar) ile planlama sistemindeki merkeziyetçi baskı, bütüncül ve stratejik olmayan, sadece fiziksel boyutta kalan planlar üretilmesi gibi etkenlerden dolayı mutlak korumanın sağlandığından söz etmek mümkün olamamaktadır. Giderek rattan ve baskın olan bu etkenler özellikle İstanbul'da günden güne sürdürülemez bir çevre yaratmaktadır. Bu alanlardan biri de İstanbul Tuzla İlçesi'ndeki doğal sit alanı Kamil Abduş Gölü'dür. Göl, önceleri çeşitli balık ve kuş türleri açısından önemli bir koruma alanı iken zamanla yapılan yanlış müdahaleler ve çevresine getirilen arazi kullanım kararları ile zaman zaman kuruma noktasına gelmiş bir lagün gölüdür. Bu çalışmada, Kamil Abduş Gölü ve Çevresindeki mekânsal değişim kronolojik olarak analiz edilmiştir. Göl ve çevresine getirilen plan kararları incelenerek lagün gölü olma özelliğini, hangi planlama kararları ve bilinçsiz müdahaleler ile kaybettiği tespit edilmiş, göl ve çevresinin yeniden kazanılması amacıyla hangi müdahalelerde bulunulduğu ve tüm bunların sonuçlarının doğal sit alanına yansımaları ortaya konulmuştur. Bu amaçla, Tuzla Belediye Başkanlığı arşivi, İstanbul Büyükşehir Belediye Başkanlığı arşivi, TC. Deniz Kuvvetleri Komutanlığı Seyir Hidrografi ve Oşinografi Dairesi Başkanlığı, Tuzla kent tarihi ile ilgili yerel kaynaklar tarafından yazılmış kitaplar, sahanın tarihsel fotoğrafları, sahanın günümüzdeki durumu, alanda analiz çalışmaları ve yerel kütüphanelerden yararlanılmıştır.

\section{Doğal Alanlar ve Koruma}

İnsanlar tarafindan en çok tüketilen ancak korunmasına ve gelecek nesillere aktarılmasına en fazla ihtiyaç olan bölgelerin başında doğal alanlar gelir. Doğal alanlarda önlenemeyen tahribatlar (Hatay-Amik Gölü, Burdur- Kestel Gölü, Kahramanmaraş Gavur gölünün sıtma ile mücadele ve tarım alanı açmak için kurutulması gibi, orman alanlarının tarım alanı ya da yaşam alanı açma için tahrip edilmesi gibi, göçmen kuşların konaklama ve uçuş güzergahlarının çevresindeki yüksek yapılaşmalar- Validebağ Korusu ya da büyük yatırımlar - İstanbul havalimanı ile kısıtlanması gibi ya da önlenemeyen yangınlar2013 yılındaki Gelibolu Yarımadası Milli Parkı gibi) nedeni ile yok olması karşısında çözüm arayışları korumaya yönelik adımlar atılmasını getirmiştir. Bu adımlara yönelik yaptırımı en kuvvetli olan araç konuyla ilgili geliştirilen uluslararası anlaşmalar ve yasalardır. Kökenlerinin yerel düzeylerde olmasına karşın çevre sorunsalını oluşturan çok sayıda sorunun, zaman içerisinde, sınır-ötesi, bölgesel ve nihayet küresel sonuçlar yarattığı ve böylece sorunsalın insanlığın ve tüm gezegenin geleceğini tehdit ettiğ tartışmasız bir gerçektir. Ortaya çıkan ve çıkacak olan olumsuz sonuçlardan hiçbir devletin ve hiçbir kimsenin kaçamayacağı gerçeği sorunun çözümünün sadece ulusal düzeylerdeki girişimlere bırakılamayacağını, küresel ve bölgesel çabaların zorunluluğunu ortaya koymuştur. Bu olgunun somut anlamı, hiçbir kişi, örgüt ya da devlet bu sorunsalın ortaya çıkmasında da masum olmadığından, herkese

8 | P a g e 
yükümlülükler getirilmesinin ve herkesin bunları yerine getirmesinin kaçınılmazlığıdır. Çünkü sonuçta tüm insanlık için ortak olan bir soruna getirilecek çözümler yine tüm insanlı̆ğın yararına olacaktır. $\mathrm{Bu}$ nedenle bu sorunlar 1970 'lerde belirgin şekilde küresel gündeme getirilmiş ve günümüze kadar değişik düzeylerde sayısız adımlar atılmıştır. Küreselleşme süreci uluslararası alanda görülen sorunların çözümü konusunda hızlandırıcı bir etki yapmış ve ulusların bu konularda beraber çalışmasını sağlamıştır. $\mathrm{Bu}$ konuyla bağlantılı en önemli örneklerden biri çevre sorunlarıdır. Küreselleşme süreci, çevre sorunları konusunda ulusal devletleri bir araya getirerek çözüm önerilerinin oluşması, uluslararası kurallar koyulmasını sağlamıştır. Çevre konusundaki çok taraflı (Birleşmiş Milletler ya da bölgesel düzeyde/ kıtalar ölçeğinde kabul edilen) belgeler özellikle 1972 BM İnsan Çevresi Konferansından (Stockholm Konferansı) sonra kabul edilmiş olup günümüzde sayıları gittikçe artmıştır.

1972 Stockholm-İnsan ve Çevre Konferansında kalkınma ve gelişme ile çevre koruma kavramları birlikte ele alınmıştır ve dünyanın geleceği bu açıdan tartışılmaya başlanmış (TBB 2014), Dünya Koruma Stratejisi, Uluslararası Doğal Kaynakları ve Doğayı Koruma Birliği (International Union for the Conservation of Nature and Natural Resources-IUCN), Dünya Yabani Hayat Fonu (World Wildlife Fund-WWF) ve Birleşmiş Milletler Çevre Programı-BMÇP (United Nations Environment ProgrammeUNEP) tarafindan hazırlanarak 1980 yılında yayımlanmıştır. Dünya Koruma Stratejisi, sürdürülebilir bir topluma ulaşmak için koruma ve geliştirme düşüncesinin birlikte ele alınması gerektiğini vurgulamaktadır. "Sürdürülebilir Gelişme" kavramı, ilk olarak Dünya Koruma Stratejisi'nde kullanılmıştır. 1983 yılında dönemin Norveç Başbakanı Gro Harlem Brundtland başkanlığında Dünya Çevre ve Kalkınma Komisyonu (WCED) kurulmuştur. 1992'de Rio de Janeiro'da gerçekleştirilen BM Çevre ve Kalkınma Konferansı'na (UNCED), İstanbul 1996- B.M. İnsan Yerleşimleri Konferansı-Habitat II, 1997 Newyork- Rio +5 Forumu, 2000 yilında New York'ta, 2002 yilında Johannesburg'ta "BM Çevre ve Kalkınma Konferansı kararlarında, temel olarak alınan kararların uygulanmasındaki etkinliğin değerlendirilmesi, yerel yönetimlerin, sivil toplum kuruluşlarının rolü, karşılaşılan güçlükler ve bu güçlükleri aşmak yönünde alınacak tedbirler ile daha etkili kalkınma stratejilerinin oluşturulması temel tartışma konuları olmuştur (Yalçıner 2005)

Uluslararası Doğa Koruma Birliği (IUCN) ise; doğanın çeşitliliğini ve bütünlüğ̈nü korumak ve geleceğe aktarmak adına tüm ülkeleri çatısı altında toplamayı hedeflemiş olan uluslararası bir doğa koruma organizasyonudur. 5 Ekim 1948 tarihinde gerçekleştirilen uluslararası bir konferansın ardından "Doğanın Korunması için Uluslararası Birlik (International Union for Protection of Nature-IUPN) adı ile kurulan, 1990 senesinde Dünya Koruma Birliği (World Conservation Union-IUCN) olarak nihai halini alan dünyanın ilk uluslararası doğa koruma organizasyonu olarak kurulan IUCN, kendi hedefini söyle tanımlamaktadır: "doğanın çeşitliliğini ve bütünlüğünü korumak, doğal kaynakların eşit ve ekolojik sürdürülebilir kullanımını sağlamak için, dünya düzeyindeki tüm toplumları etkilemek, cesaretlendirmek ve desteklemek" (Nagel 2003). IUCN düzenli olarak koruma adına ülkelerarası ortak bir dil sağlamayı, üye ülkelere teknik destek sağlamayı, koruma alanlarına yönelik uluslararası standartlar belirlemeyi, koruma uygulamalarının planlanmasını ve uygulamasını güncel tutmayı hedefleyen yaklaşımlar üretmektedir. Bunun yanı sıra bugün dünyada uluslararası düzeyde en yaygın kabul gören yerinde (insitu) koruma kategorileri, IUCN' nin koruma alanları ile UNESCO'nun biyosfer rezervleri ve dünya miras alanlarıdır. Dünya Doğayı Koruma Stratejileri bir antlaşma ya da sözleşme değildir. Genel bir deklarasyondur. Lean ve Hinrichsen 1992 yılında yaptı̆̆ı açıklamaya göre 1980 yılında yayınlanmasını takiben bu öneriler elliyi aşkın ülkede koruma ile ilgili ulusal ve yerel stratejilerin belirlenmesinde kullanılmıştır (Ortaçeşme, Karagüzel, Atik 1998). IUCN farklı ülkelerle korunan alanlar adına ortak bir anlayış yakalamak amacıyla korunan alanları kategorilere ayırmış ve amaçlarını belirlemiştir. $\mathrm{Bu}$ kategoriler sayesinde birçok ülkede korunan alanın tanımına yönelik standart belirlenmiştir. IUCN kategorileri, korunan alan yönetimine ilişkin öneriler sunmaktadır. Belirlenen kategoriler, Birleşmiş Milletler gibi uluslararası kuruluşlar ve pek çok ülke tarafindan, korunan alanların tanımlanması ve verilerin kayıt altına alınması konusunda küresel standart olarak kabul edilmiştir. Dolayısıyla gittikçe artan bir şekilde ülkelerin yasalarına dahil edilmektedir (Dudley 2008). Dünya Koruma Birliği korunan alanları altı kategoriye ayırmaktadır. Bu kategoriler; I- Mutlak Doğa Rezervi ve Yabanıl Alan; I-a: Tabiat Rezervi;. I-b: Yaban Hayatı Alanı; II- Milli Park, III- Tabiat Anıtı, ,IV- Yaşam/Tür Koruma Alanı, VKara/Deniz Peyzajını Koruma Alan, VI- Yönetilen Doğal Kaynak Koruma Alanı'dır (Dudley 2008).

Ülkemiz, IUCN'e Devlet Temsilcisi statüsü ile 1 Ocak 1993 senesinde üye olmuş ve özellikle 27-28 Mayıs 2004 tarihinde Ankara'da gerçekleştirilen “Türkiye - IUCN İlişkileri” konulu toplantının ardından daha etkin bir iletişime ve işbirliğine geçilmiştir. Ülkemizden T.C. Orman ve Su İşleri Bakanlığı (Devlet temsilcisi), WWF-TR/Doğal Hayatı Koruma Vakfı (STK), Türkiye Tabiatını Koruma Vakfı (STK), Türkiye Erozyonla Mücadele, Ağaçlandırma ve Doğal Varlıkları Koruma Vakfı (TEMA) (STK), Doğa Derneği (STK) IUCN'e üyedirler (Tarım ve Orman Bakanlığı 2018).

Doğal alanların ve yaşam alanlarının, çevrenin korunması ve sürdürülebilir olması için uluslararası

9| P a g e

www.iiste.org 
düzlemde bu adımlar atılırken, ülkemizdeki doğal mirasın korunması çabalarının geçmişine baktı̆̆ımızda 19. yüzyılın ilk yarısına uzanmakta olduğunu görmekteyiz. Osmanlı Dönemi’nde çıkarılan kanunname ve nizamnamelerle ilk olarak orman alanları koruma altına alınmıştır. Bu konudaki çabalar II. Dünya Savaşı sonrasında yoğunluk kazanmış, yasal ve kurumsal düzenlemeler ve milli parkların ilanı 1950'li yıllarda başlamıştır. 1983 yılında çıkarılan 2873 Sayılı Milli Parklar Kanunu doğal mirasın korunması yönündeki en önemli yasal çerçeveyi oluşturmaktadır. Doğal ve özellikle kültürel değerlerin bir alan bütünlüğü içinde tanımlanması, sınıflandırılması ve buna göre koruma önlemlerinin alınması, Türk mevzuatına ilk olarak 1973 yılında, 1710 sayılı "Eski Eserler Yasası” ile girmiştir. Sit kavramı çağdaş tanımına kavuşturularak, anıt, külliye, ören yeri, doğal sit ve arkeolojik sit kavramları da yasa kapsamına alınmıştır (Türk 1995).

1983 yılında bu yasa yerine günümüzde de korumaya yönelik en önemli yasal düzenlememiz olan 2863 sayılı Kültür ve Tabiat Varlıkları Koruma Kanunu çıkarılmıştır. Kanunun 13.maddesinde "Doğal (tabii) Sit”; jeolojik devirlere ait olup, ender bulunmaları nedeniyle olağanüstü özelliklere sahip yer üstünde, yer altında veya su altında bulunan korunması gerekli alanlar" (KTVK kanunu, 1983: Md.13) olarak tanımlanmış ve bu alanların nasıl korunmas1/ değerlendirilmesi gerektiği ilke kararlarında açıklanmıştır. Kültür Varlıklarını Koruma Yüksek Kurulu tarafından 19.06.2007 gün ve 728 No'lu İlke Kararı ile sit dereceleri ve müdahaleleri belirlenmiştir. Buna göre 3 derece belirlenerek;

I. Derece Doğal (Tabii) Sit Alanları için; "Bilimsel muhafaza açısından evrensel değeri olan, ilginç özellik ve güzelliklere sahip olması ve ender bulunması nedeniyle kamu yararı açısından mutlaka korunması gerekli olan, korumaya yönelik bilimsel çalışmalar dışında aynen korunacak alanlardır. Bu alanlarda, bitki örtüsü, topografya, silüet etkisini bozabilecek, tahribata yönelik hiçbir eylemde bulunulamayacağı" kararı getirilerek istisnai durumları belirtilmiştir.

II. Derece Doğal (Tabii) Sit Alanları ilke kararında; "Doğal yapının korunması ve geliştirilmesi yanında kamu yararı gözönüne alınarak kullanıma açılabilecek alanlardır. Bu alanlarda, turizm yatırım ve turizm işletme belgeli turistik tesisler ile hizmete yönelik yapılar dışında herhangi bir yapılaşmaya gidilemeyeceği” belirtilmiştir. Kullanıma açılacak bölgelerde geçici dönem yapılanma koşullarının ilgili kurumların görüşleri alınarak Koruma Kurullarınca belirlenmesine, bu belirlemede varsa çevre düzeni planı veya nazım plan kararları ile arazinin topografya, peyzaj, silüet vb. karakteristiklerinin gözönünde tutulmasına, ancak hazırlanacak Koruma Amaçlı İmar Planı kriterlerini etkileyebilecek nitelik ve yoğunluktaki uygulamalara Koruma Amaçlı İmar Planı yaptırılmadan izin verilemeyeceği de ilke kararı olarak alınmıştır.

III. Derece Doğal (Tabii) Sit alanları ise; doğal yapının korunması ve geliştirilmesi yolunda, yörenin potansiyeli ve kullanım özelliği de gözönünde tutularak konut kullanımına da açılabilecek alanlardır (KVKYK 19.06.2007 gün ve 728 no'lu ilke kararı).

Öte yandan18 Temmuz 2012 yılında 28358 sayı ile Resmi Gazetede yayınlanarak yürürlüğe giren Korunan Alanların Tespit, Tescil ve Onayına İlişkin Usul Ve Esaslara Dair Yönetmeliği'nde ise, (RG:19.07.2012, Sayı: 28358, Md.6) doğal sitler için tanım ve kategoriler yeniden düzenlenmiştir. Yönetmeliğin amacı; milli park, tabiat parkı, tabiat anıtı, tabiatı koruma alanı ve sulak alanların tescil, onay ve ilanı ile tabiat varlığı, doğal sit alanı ve özel çevre koruma bölgelerinin tespit, tescil, onay, değişiklik ve ilanına dair usul ve esasların belirlenmesidir (RG:19.07.2012, Sayı: 28358, Md.1). Korunan Alanların Tespit, Tescil ve Onayına İlişkin Usul ve Esaslara Dair Yönetmeliği’ne göre ilan edilecek olan doğal sitler; "kesin korunacak hassas alanlar", "nitelikli doğal koruma alanları", ve "sürdürülebilir koruma ve kontrollü kullanım alanları” olmak üzere üç farklı kategoriye ayrılarak tanımlanmıştır.

- Kesin Korunacak Hassas Alan: Bölgesel, ulusal veya dünya ölçeğinde olağanüstü ekosistemlerin, türlerin, habitat ve jeolojik jeomorfolojik özelliklerin korunduğu, genel olarak insan etkisi olmadan meydana gelmiş, insan faaliyetleri sonucu bozulma veya tahrip olma riski yüksek olan alanları (RG:19.07.2012, Say1: 28358, Md.4),

- Nitelikli Doğal Koruma Alanı: doğal yapısı değişmemiş veya az değişmiş, modern yaşam ve önemli ölçüde insan faaliyetleri tarafindan etkilenmemiş, doğal süreçlerin hâkim olduğu, koruma amaçlarına uygun olarak yörede yaşayanların alanın mevcut kaynaklarını kullanmasını sağlayarak doğal hayata dayalı geleneksel yaşam şekillerinin korunduğu kara, su, deniz alanları (RG:19.07.2012, Sayı: 28358, Md.8),

- Sürdürülebilir Koruma ve Kontrollü Kullanım Alanı: Kesin korunacak hassas alanlar veya nitelikli doğal koruma alanlarını etkileyen, bu koruma bölgeleri ile bütünlük gösteren, korumaya katkı sağlayacak, doğal ve kültürel bakımdan uyumlu düşük yoğunlukta faaliyetler, turizm ve yerleşimlere izin veren alanlardır (RG:19.07.2012, Sayı: 28358, Md.9).

Çevreye yönelik koruma kanunlarından bir diğeri ise 1983 tarihli 2872 sayılı Çevre Kanunu'dur. 2872 sayılı Çevre Kanununun amacı "bütün canlıların ortak varlığı olan çevrenin, sürdürülebilir çevre ve sürdürülebilir kalkınma ilkeleri doğrultusunda korunmasını sağlamaktır.” şeklinde tanımlanmıştır. Çevre

$10 \mid \mathrm{P}$ a g e

www.iiste.org 
Kanununun 9.maddesine göre "Ulusal mevzuat ve taraf olduğumuz uluslararası sözleşmeler ile koruma altına alınarak koruma statüsü kazandırılmış alanlar ve ekolojik değeri olan hassas alanların her tür ve ölçekteki plânlarda gösterilmesi zorunludur. Koruma statüsü kazandırılmış alanlar ve ekolojik değeri olan alanlar, plân kararı dışında kullanılamaz." Ayrıca "Sulak alanların doğal yapılarının ve ekolojik dengelerinin korunması esastır. Sulak alanların doldurulması ve kurutulması yolu ile arazi kazanılamaz. Bu hükme aykırı olarak arazi kazanılması halinde söz konusu alan faaliyet sahibince eski haline getirilir" şeklinde hükümleri bulunmaktadır. Bu çalışmanın inceleme alanı olan Kamil Abduş Gölü, bir lagün gölü olması dolayısı ile aynı zamanda bir sulak alan statüsündedir. Sulak Alan; bir takım ortak özelliklere sahip olan kıyıdan uzak alanları, kıyı ve deniz yataklarını genel olarak kapsamına almaktadır.

Sulak Alanlar, Sulak Alanların Korunması Yönetmeliği’nde (RG:04.04.2014, Sayı: 28962) korunma hiyerarşisine göre; Mutlak Koruma Bölgesi, Hassas Koruma Bölgesi, Tampon Bölge, Kontrollü Kullanım Bölgesi ve Sürdürülebilir Kullanım Bölgesi olmak üzere 5 kategoriye ayrılmıştır.

- Mutlak Koruma Bölgesi; Koruma bölgeleri içerisinde yer alan, su kuşlarının yoğun ve toplu olarak kuluçka yaptığı, konakladığı veya kışladığı alanlar; nadir ve nesli tehlikedeki kuş türlerinin önemli üreme bölgeleri, uluslararası ölçütlere göre tehlike sınırı en az hassas düzeyinde olan türlerin bağımlı oldukları habitatlar ile nesli tehlikede ve dar yayılışlı olup, korunması gerekli doğal bitki türlerinin bulunduğu, insan faaliyetlerinin mevcut olmadığı bölgeleri (md.4 bend: r),

- Hassas Koruma Bölgesi; Varsa mutlak koruma bölgesini korumak maksadı ile yoksa sulak alan ekosisteminin mevcut karakterini korumak maksadı ile belirlenen kendi kendine onarım potansiyeli olan, açık su yüzeyleri, lagünler, nehir ağızları, tuzlalar, geçici ve sürekli tatlı ve tuzlu su bataklıkları, sulak çayırlar, sazlıklar ve turbalıklar ile bu ekosistemleri ekolojik olarak destekleyen kumul, kumsal, çalılık, ağaçlık, subasar orman gibi habitatların bozulmadan korunması gereken bölgeleri (md.4 bend: 1),

- $\quad$ Tampon Bölge; Sulak alan havzasının coğrafi durumu, topoğrafik özellikleri ve arazinin mevcut kullanım durumuna göre; sulak alan ekosistemini korumak maksadı ile tanımlanan ve sulak alanın su toplama sınırını geçmeyen veya topoğrafik, coğrafik olarak bir sınır değeri bulunmayan düz alanlarda ise varsa sürdürülebilir kullanım bölgesi, yoksa hassas koruma bölgesi sınırından itibaren bilimsel esaslara dayanarak alanın ekosistem özellikleri dikkate alınarak komisyon tarafından belirlenen bölgeyi ( $\mathrm{md}: 4$ bend: çç),

- $\quad$ Kontrollü Kullanım Bölgesi; Koruma bölgeleri belirlenmeden önce kurulmuş veya sulak alanın bölgelemesi sırasında belirlenmiş, yerleşim ve kentsel gelişim için zorunlu olan, insan faaliyetlerinin yoğun olduğu ve bu faaliyetlerin sulak alan ekosistemine olumsuz etkilerinin asgariye indirilmesi için gerekli tedbirlerin alındığı bölgeleri (md:4 bend: k),

- Sürdürülebilir Kullanım Bölgesi; Doğal veya yarı doğal olmak üzere, açık su yüzeyleri, lagünler, nehir ağızları, tuzlalar, geçici ve sürekli tatlı ve tuzlu su bataklıkları, sulak çayırlar, sazlıklar ve turbalıklar ile bu ekosistemleri ekolojik olarak destekleyen kumul, kumsal, çalılık, ağaçlık, subasar orman gibi habitatlarda insanların balıkçılık, sazcılık, turba çıkarımı, ormancılık, toplayıcılık, tarım ve hayvancılık gibi ekonomik faaliyetlerinin geleneksel olarak sürdürülmesine izin verilen bölgeyi (md:4 bend: a) oluşturmaktadır.

Sulak alanların korunması ile ilgili en önemli yasal belge olan ve 1971 yılında İran'ın Ramsar kentinde imzaya açılan Sulakalanların Korunmasına Dair Sözleşme (RAMSAR)’ye Türkiye 30 Aralık 1993 tarihinde taraf olmuş, sözleşme 94/5434 sayılı Bakanlar Kurulu Kararıly 17.05.1994 tarihi ve 21937 sayılı Resmi Gazete'de yayımlanmış ve yürürlüğe girmiştir. Ramsar Sözleşmesi; sulak alanların bulunduğu bölgenin su rejimini düzenlemesi, karakteristik bitki ve hayvan topluluklarını; özellikle su kuşlarının barınmasına olanak sağlaması, ekonomik, kültürel, bilimsel ve rekreasyonel olarak büyük bir kaynak teşkil etmesi, kaybedilmeleri halinde bir daha geri kazanılmasının mümkün olmaması nedeniyle sulak alanların kaybına neden olabilecek hareketleri önlemek ayrıca su kuşlarının mevsimsel göçleri sırasında sınırlar aşması nedeniyle uluslararası bir kaynak olduğunu tanıyarak; sulak alanların ve onlara bağımlı bitki ve hayvan topluluklarının korunmasının ileri görüşlü ulusal politikalarla koordineli uluslararası faaliyetlerin birleştirilmesini sağlamak amacıyla hazırlanmış bir sözleşmedir (Ceran 2007). $\mathrm{Bu}$ sözleşme ile birlikte ülkemizin taraf olduğu diğer uluslararası sözleşmeler ve Resmi Gazatede yayınlanarak yürürlüğe giriş tarihleri söyledir:

11 | P a g e

www.iiste.org 
1972 Paris- Dünya Doğal ve Kültürel Mirası Koruma Sözleşmesi: (14.02.1983 tarih ve 17959 sayı), 1973 Washington-Yaban Hayatı Koruma Sözleşmesi: (20 Haziran 1996 tarih ve 22672 Sayı),

1976- Barselona- Akdeniz'in Deniz Ortamı ve Kıyı Bölgesinin Korunması Sözleşmesi: ( 22 Ağustos 2002 tarih ve 24854 say1),

1989 Basel- Tehlikeli Atıkların Sınırlar Ötesi Taşınımının ve Bertarafının Kontrolüne İlişkin Sözleşme: ( 15 Mayıs 1994 tarih ve 21935 sayı),

1992 Rio- Biyolojik Çeşitliliği Koruma Sözleşmesi: (27 Aralık 1996 tarih 22860 sayı),

Paris (1994) - Kuraklık ve Çölleşme ile Mücadele Sözleşmesi: (16 Mayıs 1998 tarih ve 23344 sayı),

B.M. İklim Değişikliği Çerçeve Sözleşmesine Yönelik Kyoto Protokolü (1997): (13 Mayıs 2009 tarih ve 27227 Sayı) (Mutluay 2015).

Dünya Koruma Birliği'nin belirlediği korunan alanları ile ülkemizdeki koruma alanları karşılaştırıldığında Mutlak Doğa Koruma Alanları, Yabanıl Hayat Alanları I.koruma kategorisinin a ve b maddeleridir. Bu alanların ülkemizdeki denkliği Tabiat Koruma Alanları yani "Doğal Sit Alanları" ile örtüşmektedir.

\section{Bir Lagün Gölünü Koruyamamak: Kamil Abduş Gölü}

Tuzla, Marmara Bölgesinde, Kocaeli Yarımadasının güneybatısında, 15.067.724 nüfusa ulaşan İstanbul'un en doğusunda bulunan 255.468 nüfuslu (2018-Tuik-ADNKS) son ilçesidir. Marmara Denizi'ne 13 km. uzunluğunda kıyısı bulunmaktadır. Tuzla İlçesi sit alanlarıyla öne çıkmış yaklaşık 13800 hektarlık bir ilçedir (Şekil 1.).

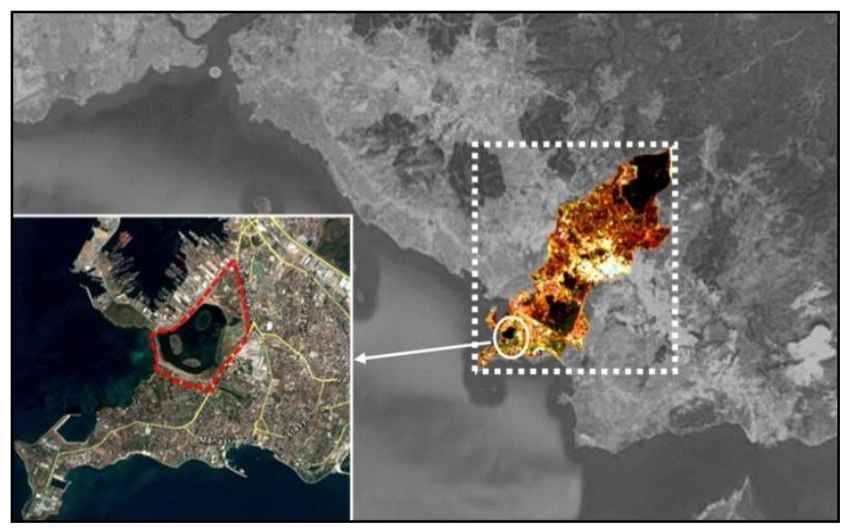

Şekil 1. Tuzla’da Kamil Abduş Gölü konumu

Tuzla İlçesi adını burada bulunan ve gerek Bizans Dönemi’nde gerek Osmanlı Dönemi'nde İstanbul'un tuz ihtiyacını karşılamış olan Tuz Gölü'nden almaktadır. Bu alanın eski adı "Akritas"dır. Akritas adı 18. yüzyıl başlarına kadar kullanılmıştır (Özkaya 1993).

İstanbul'un 1453 y1lında fethi ile beraber Tuzla, Osman Devleti yönetiminde, Cumhuriyetin ilanından itibaren de Türkiye Cumhuriyeti Devleti yönetimindedir. 30 Ocak 1923 yılında Türkiye ile Yunanistan arasında imzalanan Nüfus Mübadelesi Anlaşması'yla Tuzla'daki Rum nüfus Yunanistan'a, Yunanistan'ın çeşitli yörelerinde yaşayan Türklerin bir bölümü ise Tuzla'ya yerleştirilmiştir. 1928 yılında Gebze'ye bağlı olduğu görülen Tuzla, 1936 yılında müstakil belediye olmuşsa da 1954 tarihinde tekrar Kartal'a bağlı bir belde olmuştur. 1987'de Pendik, Kartal'dan ayrılarak ilçe yapılınca Tuzla da Pendik'e bağlanmış ve 1992'de yeniden müstakil ilçe yapılmıștır (Özdemir 2011).

Doğal sit alanlarıyla öne çıkan ilçede 7 adet doğal ve 4 adet karma sit alanı yaklaşık 217 hektarlık bir alanı kaplamaktadır. Doğal sit alanları, Büyük ve Küçük İçmeler ve çevresi (13.7 ha.), Kamil Abduş Gölü ve çevresinde (190 ha.) yer almaktadır. İlçede Sakız Adası (19.6 ha.), İncirli Adası, Antik Mendirek çevresi (10.2 ha.), doğal sit ve III. derece arkeolojik sit alanları dışında Tuzla Merkezinde kentsel sit (11.4 ha.) ve III. derece arkeolojik sit alanı bulunmaktadır.

Kamil Abduş Gölü, Tuzla İlçesinin güneybatısında, Postane Mahallesi sınırları içerisinde yer almaktadır. Batısında tersaneler bölgesi, güneyinde Marmara Denizi, kuzey doğusunda ise yine bir sit alanı olan İçmeler Kaplıcaları bulunmaktadır. Cumhuriyetin ilk yıllarında Bakanlar Kurulu kararı ile Batı Trakya'dan mübadele yolu ile Tuzlaya'ya gelen bir göçmen olan Kamil Abduş’a tahsis edilen çiftliğin içerisinde bulunduğu için resmi olarak "Kamil Abduş Gölü" olarak isimlendirilen göle "Tuzla Balık Gölü” ya da "Mercan Göl” de denilmektedir (Aydın 1992).

Tuzla İçmeleri’nin güneybatısında, Marmara Denizi sahilinde yer alan Kamil Abdus Gölü, yapı olarak bir lagün gölüdür. Denizle arasında bir kıyı kordonu vardır. Kamil Abduş Gölü, başlangıçta batıdan küçük 
tepelerle çevrili bir çukur alanın deniz sularının altında kalmasıyla önü adalarla sınırlı bir koy durumuna girmiştir. Aydınlı Limanı'nı çevreleyen bu tepeler; Umurbey Deresi'nin denize karıştığı yerdeki Mankafa Tepe, güneyde Sakız Tepe ve Sakız Tepe'nin batısındaki Ekrem Bey Adası ve gölün güneyindeki Köşk Tepedir (Şekil 2.).

Zamanla akarsuların getirdiği malzeme koy gerisinde alçak bir kıyı ovası oluşturmuş ve Sakız Tepe doğal bir kıyı kordonu ile karaya bağlanarak bir tombolo ${ }^{1}$ durumuna girmiştir. Marmara Denizi’nin lodos fırtınaları ile çıkardığı kum seddeleri Aydınlı Limanı'nın arka kesiminin denizden ayrılarak göl haline dönüşmesine neden olmuştur. Gölün güneybatı kesiminin lodosa daha açık olması nedeni ile bu kesim daha yüksek bir kum sedddesi ile dolmuş ve doğal bir plaj haline gelmiştir. Bu kum seddesi ile derenin getirdiği mil Mankafa Tepe'yi doğrudan çevrelediği için Tuzla Gölü ile Köşk Tepe arasında küçük bir gölcük oluşmuştur. Sakız adası Aydınlı Limanı’nın güney kesimini lodostan koruduğu için bu kesim kumlarla fazla dolmamış ve göl deniz arasındaki bağlantı bu kesimde korunmuştur (Tuncay 2016) (şekil 2.).

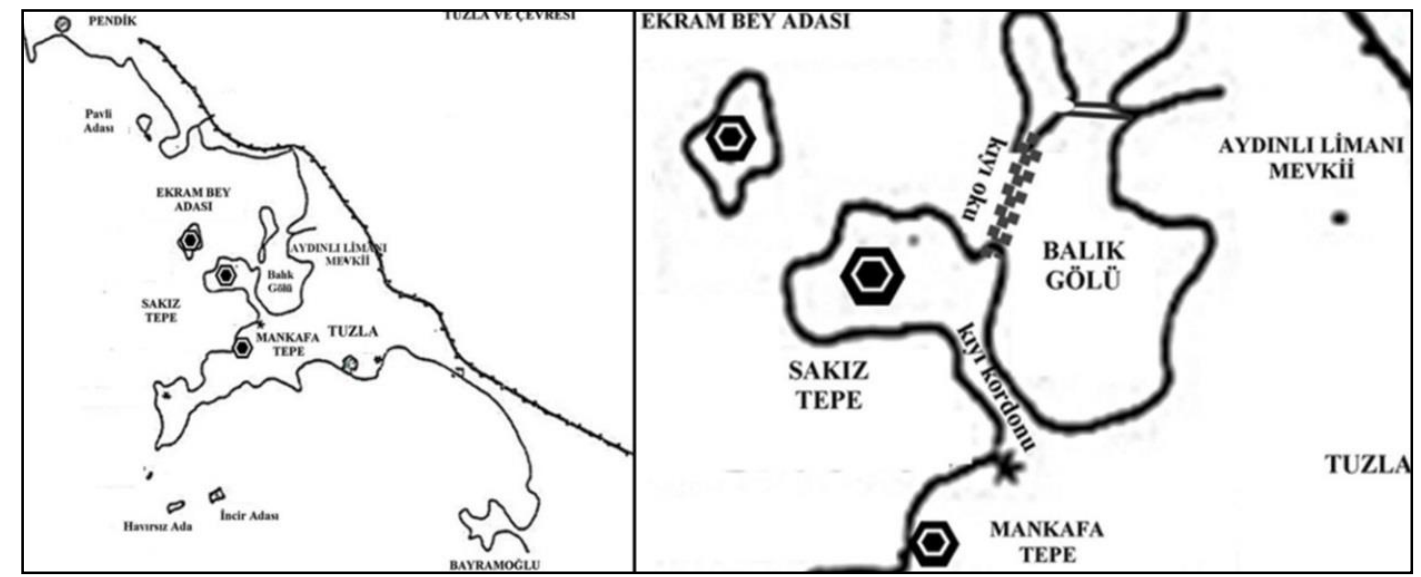

Şekil 2. Kamil Abduş Gölü (Balık Gölü) ve çevresindeki tepeler şematik gösterimi (Soyhan 1996).

Geçmişte Marmara Denizi'nin balık deposu olarak da bilinen göl, balıkların yumurtalarını bıraktığı ideal bir balık yetiştirme ortamıdır. Özellikle kefal balığı çiftlikleri için kullanılan gölün çevresinde gümüşi martı, pelikan, yaban ördeği, leylek gibi yaygın türlerin yanında kervan çulluğu, suna, çaltıkçı, kuğu gibi dünyada yok olma tehlikesindeki kuşlar da bulunmaktaydı (Doğaner 2000). Tuzla Gölü'nün denizden ayrılarak oluşmuş bir lagün gölü olması göl tabanının deniz kumu ve deniz hayvancıklarının kabukları ile oluşmasına neden olmuştur. Ayrıca Umur Dere taşkınlarının göle getirdiği mil de gölün kuzeybatı kesiminde deniz kumu ile karışmıştır. Göle taşınan milden ötürü gölün etrafında sazlıklar oluşmuş, bu sazlıklar bir yandan su kuşlarına yuva görevini görürken diğer yandan da dışarıdan atılan atıkları tutmaya devam etmiştir (Tuzla Çevre Gönüllüleri 1991). Göl, lüfer, karagöz, çupra, yılan balığı gibi balık türlerinin yaşadığı bir doğal alan olmaya devam ederken, kamulaştırılmış ve 1930'lara kadar tuz üretim alanı olarak kullanılmıştır.

Kamil Abduş Gölü ve Çevresi bir lagün gölü olmakla birlikte aynı zamanda kuşların yaşam alanı ve göç güzergâhı olma özelliği de taşımaktayken, dünyada eşine az rastlanır bu özelliklerini geçmişten günümüze kadar alınan hatalı kurumsal kararlar, müdahaleler ve yanlış uygulamalar sonucu kaybetmiştir. Kamil Abduş Gölü'nün korunamama, belki de yok oluş öyküsünü betimleyen bu karar ve uygulamaların en önemlileri şöyle özetlenebilir.

\subsection{Umur Derenin Güzergâhının Değiştirilmesi}

1950'li yıllarda gölü besleyen en önemli kaynak olan Umur Dere'nin güzergâhının değiştirilmesiyle başlayan planlama hataları bugün göl ve çevresinin korumaya değer özelliklerinin tamamının yitirilmesine sebep olmuştur. 1950'li yıllarda çevresi kırsal ekonomik faaliyetlerde (çiftliklerde) kullanılan ve bir sulak alan olan gölün, taşkınlarla çevreye zarar vermesini önlemek için, Umur Dere'nin gölü beslediği ve denize döküldüğü ağzı kuzeye çevrilmiş, kıyı okunun Sakız yarımadasında denizle bağlantı kuran kısmı kapatılmıştır. Böylece lagünün doğal beslenme şartları ortadan kaldırılmış ve alan küçülmeye başlamıştır (Doğaner 2000). Umur Derenin yönünün kuzeye doğru çevrilmesiyle önceleri

\footnotetext{
${ }^{1}$ Tombolo; deniz açı̆̆ında, kıyıya yakın bir adanın bir veya birkaç kıyı okuyla ikisini birbirlerine bağlayan, ortalarında çoğu kez lagün de bulunan oklardır. Ardos, M., Pekcan (Yalçıner), N., 1994, Jeomorfoloji Sözlüğ̈̈ (Kısmen Yerbilimleri), İstanbul Üniversitesi Edebiyat Fakültesi Yayınları No.3397, İstanbul.
} 
kıyı okunu aşarak gelen tuzlu deniz suyu ile dere taşkınlarıyla gelen tatlı su arasında oluşan tatlı-tuzlu su dengesi ve göldeki su miktarı bozulmuştur.

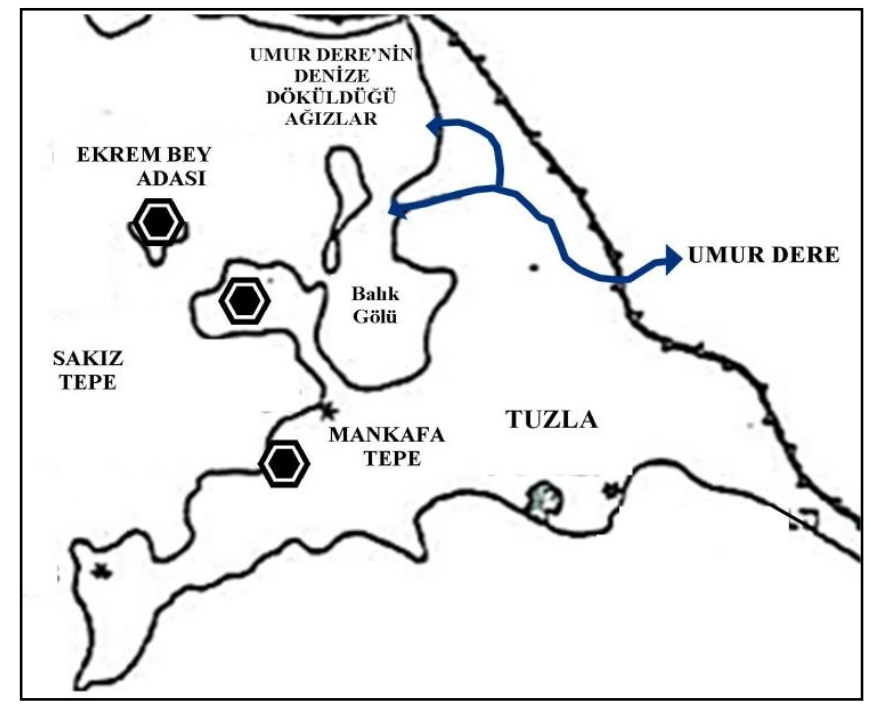

Şekil 3. 1950’li yıllarda Umur Dere güzergahının şematik gösterimi

\subsection{Yllı Tuzla Gemi İnşa Tesislerinin Kurulması}

Göl ve çevresindeki doğal niteliğin bozulmasındaki en önemli kırılma noktası 22.09.1969 gün ve 6/12421 sayılı Bakanlar Kurulu Kararıdır. Bu karar ile o dönemde Haliç kıyısında bulunan tersanelerin İstanbul'un sanayiden arındırılması amacıyla Tuzla'da bugün Tersaneler Bölgesini oluşturan alana taşınması kararlaştırılmıştır. 1969 yılında Boğaz'da ve Haliç’te yoğunlaşan özel sektör tersanelerinin toplanması için Aydınlı Koyunun seçilmesi de 1969 yılında rastlamaktadır. Türkiye kıyılarında yapılaşmanın İmar Kanununa (1956 ve 1957) göre yürütüldüğü yıllara ait olan bu yer seçiminde bu alanın kent dışında seyrek nüfuslu olması, arazinin bataklık olarak düşünülüp ıslah edilmesi, kamu tersane alanı olarak seçilen Pendik koyuna yakın olması etken olmuştur. Fakat derinliğin $1 \mathrm{~m}(0.9 \mathrm{~m})$ altına düştüğü ve rüzgarın yönüne göre dalgaların getirdiği malzemeyi yığmaya devam ettiği Aydınlı koyu fiziki coğrafi şartlar açısından gemi inşa sanayi için uygun değildir (Doğaner 2000).

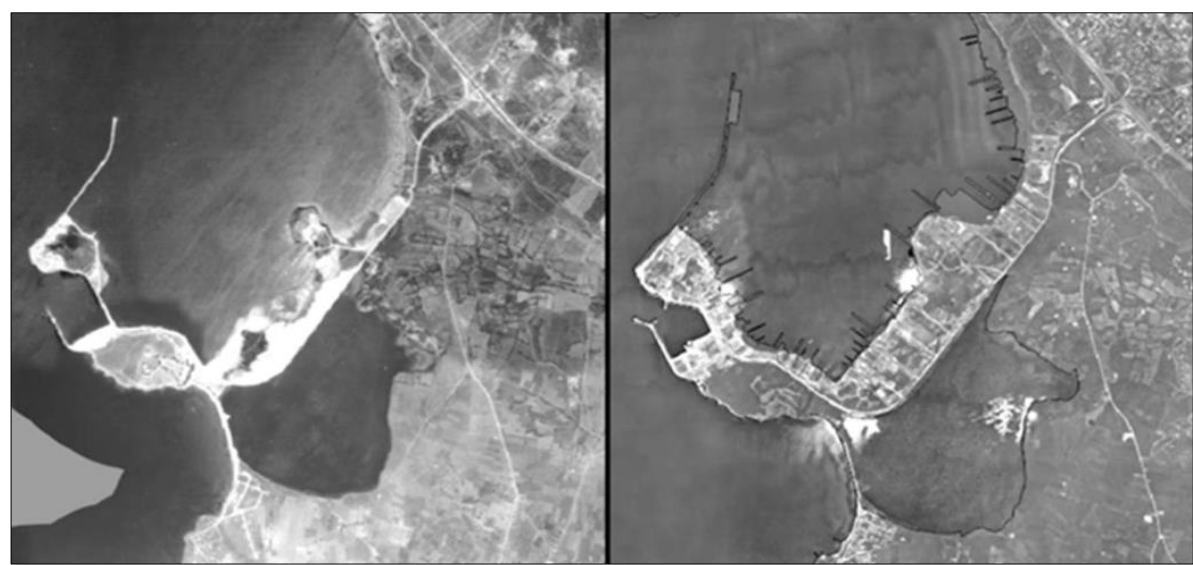

Şekil 4. Tersane bölgesi öncesi (1970 yılı) ve sonrası (1982 yılı) Kamil Abduş Gölü ve Çevresi (https://sehirharitasi.ibb.gov.tr)

1970'li yıllardan itibaren başlayan altyapı çalışmaları sırasında Ekrem Bey Adası, Sakız Yarımadası'na bağlanarak, koy güneybatı rüzgârlarına karşı korunmalı duruma getirilmiş ve batı rüzgârlarına karşı korunmak için de mendirek yapılmıştır. Gölü denizden ayıran kıyı çevresinde geniş bir alan doldurularak gölün bu kısmının denizle bağlantısı kesilmiş, göl ve tersaneleri ayıran karayolu bu dolgu sahası üzerinden geçirilmiş, denizden kazanılan alan üzerine özel tersaneler için faaliyet alanı düzenlenmiştir (An11 2005). 


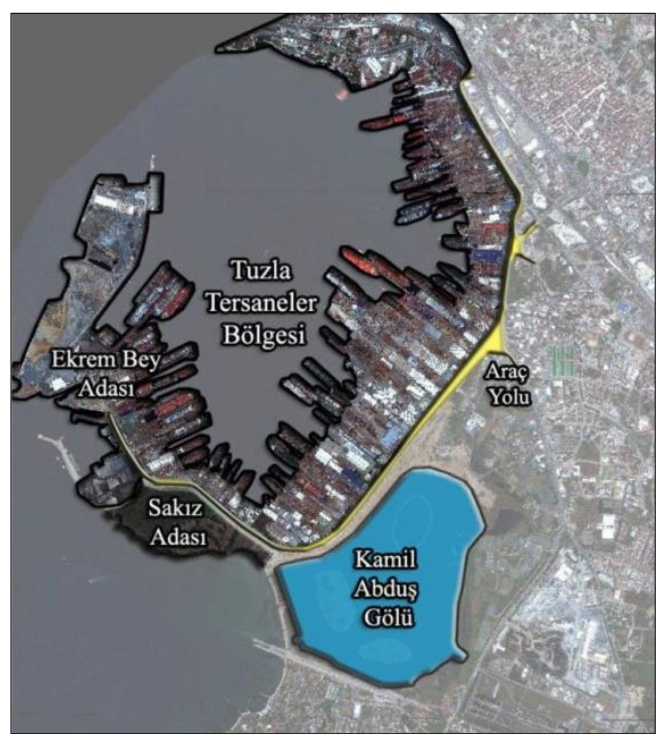

Şekil 5. Kamil Abduş Gölü ve doldurulan alanda kurulan

Tersaneler Bölgesi arasında düzenlenen araç yolu (Duman 2019)

1980’li yıllarda Kamil Abduş Gölü ve yakın çevresinde yerleşim bulunmamakla birlikte tersanelerin bölgeye gelmesiyle yaşanan kirlilik 1950'li yıllarda derenin ağzının yönünün değiştirilmiş olmasıyla birleşince gölün alanı küçülmeye başlamıştır. 1982 yılı arazi kullanımı incelendiğinde lagünde ağırlıklı olarak tarım yapıldığı görülmektedir. Ayrıca lagündeki faunanın devamlılığını sağlayan ve koruma dengesini oluşturan sazlık-bataklık alanın tarım arazisi ile lagün arasında tampon bölge oluşturarak doğal yollardan arındırıcı nitelik sağladığı görülmektedir. 1982 yılında göl çevresinde yapılan fiziksel değişimlerin etkileri yeni yeni lagün gölüne yansımaya başlamıştır.

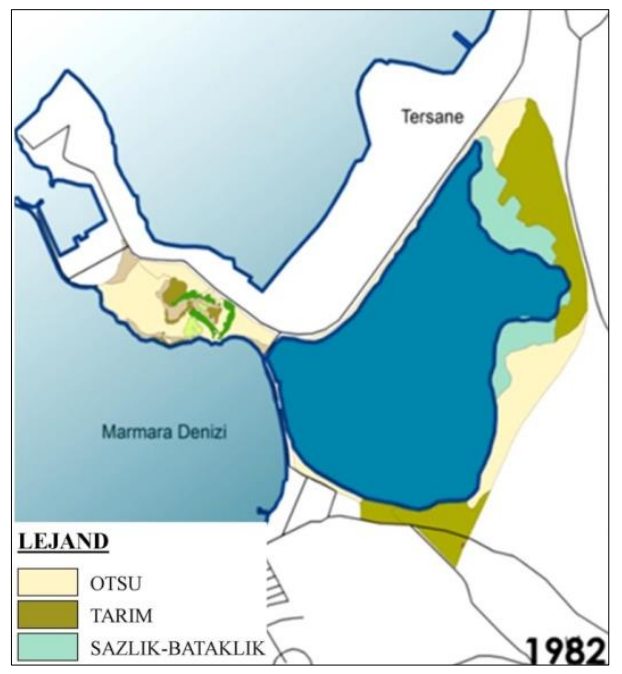

Şekil 6. Kamil Abduş Gölü’nün 1982 yılına ait arazi kullanımı (Tuncay 2016)

\subsection{Tuzla 1985 Nazım Imar Planı ve 1986 yılı Uygulama Imar Planı İlanları}

4 Aralık 1984 yılında Yıldız Üniversitesi (bugünkü Yıldız Teknik Üniversitesi) ile İstanbul Büyükşsehir Belediyesi arasında imzalanan protokol ile Tuzla'nın 1/5000 ölçekli nazım imar planı ve 1/1000 ölçekli uygulama imar planı çalışmaları yapılmıştır. Tuzla İlçesi 1/5000 Ölçekli Nazım İmar Planı İstanbul Büyükşehir Belediye Meclisinin 20.12.1984 tarih ve 238 sayılı kararı ile 02.01.1985 tarihinde onaylanmıştır (şekil 10.).Tuzla'nın yapılan ilk planları olan 1/5000 ölçekli nazım imar planında Kamil Abduş Gölü'nün kuzeybatısına Tersane fonksiyonu, batısında bulunan ve bugün arkeolojik sit alanı olan Sakız Adası ise Askeri Bölge fonksiyonu olarak düzenlenmiştir. Göl henüz sit alanı ilan edilmediğinden çevresine yapılaşma önerileri getirilmiştir. Kuzeyinde dönemin yüksek yoğunluklu konutları için tasarlanan yoğunluk değeri olan 300 ki/ha yapılaşma koşullu konut alanları, park alanları, spor alanları, 
güneyinde ise yapılaşma yoğunluğu azaltılarak $120 \mathrm{ki} /$ ha yapılaşma koşullu konut alanları, hastane alanı gibi fonksiyonlar düzenlenmiştir. Bölgenin doğusuna bugünkü İSTON fabrikasının ve arıtma tesislerinin plan temeli atılmış ve ilk kez bu planla bu bölgede İSKİ Pis Su Arıtma Tesisi fonksiyonu planlanmıştır. Haliç Bölgesini tersanelerden arındırmak amacıyla plansız bir alana Bakanlar Kurulu Kararı ile getirilen Tersane Alanı ise ilk kez bu planlarda işlenmiştir. Kartal Tuzla 1/1000 Ölçekli İmar Uygulama Planı İstanbul Büyükşehir Belediye Meclisinin 06.12.1985 tarih ve 597 sayılı kararı ile 31.03.1986 tarihinde onaylanmıştır (şekil 8.).

1/5000 ölçekli nazım imar planı kararları doğrultusunda yine Yıldız Üniversitesi tarafindan hazırlanan 1/1000 ölçekli imar uygulama planında Kamil Abduş Gölü’nün kuzeyinde kitle imarlı konut fonksiyonları, donatı fonksiyonlarına yönelik çocuk bahçesi, ilkokul alanları düzenlenmiştir. Göl kıyısında sahip olduğu potansiyeli değerlendirmek amacıyla park alanları, kamp alanları, iskeleler planlanmıştır. Bugünkü İSTON fabrikasının ve arıtma tesislerinin bulunduğu bölge 1/5000 ölçekli planlara uyumlu olması amacıyla 1/1000 ölçekli planlarda da İSKİ Pis Su Tasfiye Alanı olarak planlanmıştır. Tersane alanı ile göl arasında oluşturulan araç yolu aksı boyunca koruyucu yeşil bant oluşturmak için 1/1000 ölçekli imar uygulama planında ağaçlandırılacak alan fonksiyonları düzenlenmiştir. $\mathrm{Bu}$ durum kenti ve gölü tersane alanından ayırmak amacıyla alınmış bir planlama kararıdır.

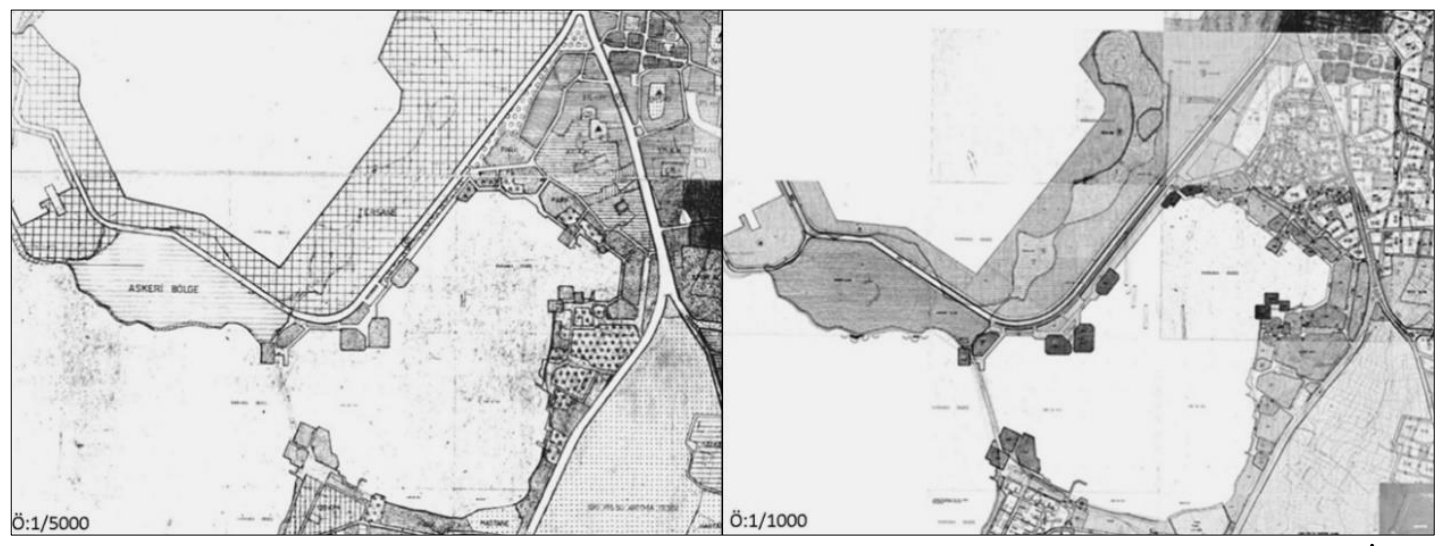

Şekil 7. 02.01.1985 tasdik tarihli 1/5000 ölçekli ve 31.03.1986 tasdik tarihli 1/1000 ölçekli Tuzla İmar Planı'nda Kamil Abduş Gölü ve Çevresi (Tuzla Belediyesi 2017)

\subsection{Yılı Tuzla ISTON Fabrikasının Kurulması}

31.03.1986 tasdik tarihli 1/1000 ölçekli Kartal Tuzla imar uygulama planı akabinde Kamil Abduş Gölü’nden yaklaşık 200 metre mesafede, yalnızca bir karayolu ile gölden ayrılan, bugün hala işlevini devam ettiren İSTON (İstanbul Beton Elemanları ve Hazır Beton Fabrikaları San. ve Tic. A.Ş) fabrikası kurulmuştur. İstanbul Su ve Kanalizasyon İdaresi'nin mülkiyetinde bulunan İSTON fabrikası kurulduğu günden beri kent içerisine kötü koku yaymakla beraber endüstriyel atıklar üreterek çevre ve Kamil Abduş Gölü ile etkileşim içinde olmuştur. Bunun yanı sıra endüstriyel üretim yapan İSTON fabrikasının sit alanları bitişiğinde bulunması yer seçimi açısından da tartışmalıdır.

\subsection{3-1997 Yılları Arası Kamil Abduş Gölü ve Çevresinde Sit Alanı İlanı}

26.11.1993 gün ve 3019 sayılı İstanbul II no’lu Kültür ve Tabiat Varlıklarını Koruma Kurulu Kararı ile Kamil Abduş Gölü 1. Derece Doğal Sit Alanı, 16.07.1997 gün ve 4535 sayılı kararı ile Gölün kuzey kesimi 2. Derece Doğal Sit Alanı olarak ilan edilmiştir. Göl ve çevresindeki sit dereceleri günümüzde geçerliliğini korumaktadır. 


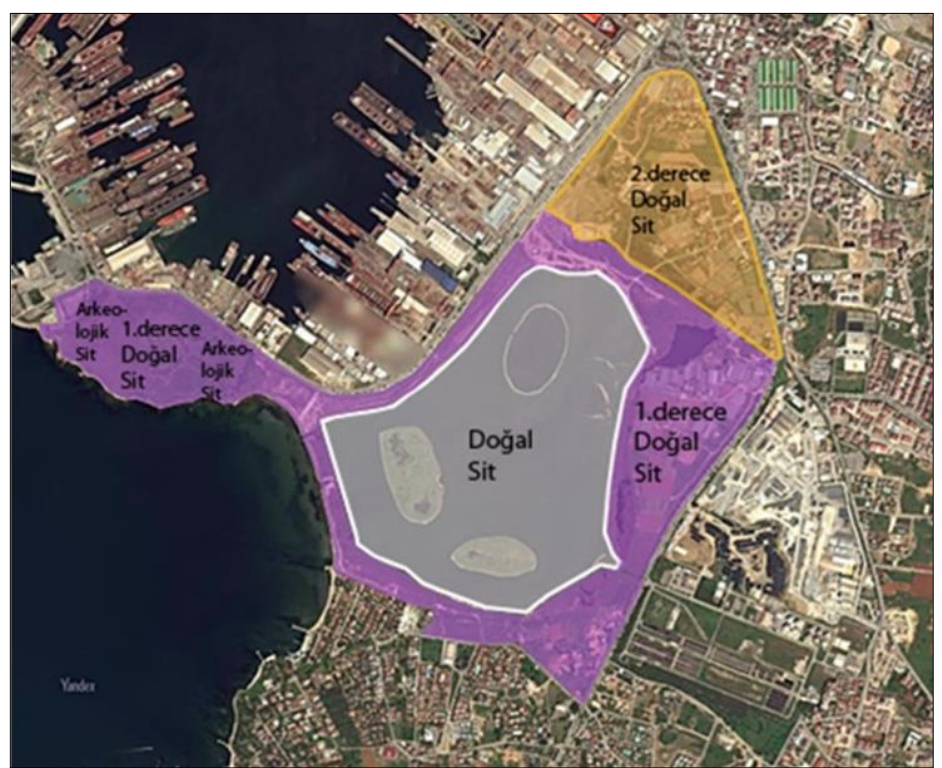

Şekil 8. Kamil Abduş Gölü ve çevresi sit alanları (Duman 2019).

2.61998 Yılı Tuzla Arttma Tesislerinin Kurulması:

1991 yılında kuruluşuna başlanan, 1998 yılında faaliyete geçen, İSTON fabrikasının güneyine, Kamil Abduş Gölü'nden yaklaşık 150-200 metre mesafede Tuzla Atıksu Arıtma Tesisleri kurulmuştur. Atıksu Arıtma Tesisleri İstanbul Su ve Kanalizasyon İdaresi'nin mülkiyetindedir. Arıtma tesislerinin atık suları 1998 yılından itibaren, Kamil Abduş gölünün çevresinden dolanarak gölün menfezinin bulunduğu noktaya bitişik noktadan denize verilmektedir. Atık su arıtma tesislerinin deşarjı, tersanelerin ve diğer kirletici endüstrinin atıkları lagünün etki alanında kaldığından gölün sahip olduğu lagün özelliğinin bozulmasının en önemli sebepleri olmuşlardır. Göl menfezinin bitişinden çıkan atık sular, denizin dalgalanmasına, rüzgârın kuvvetine, göl suyu miktarı ve derinliğine paralel olarak göl suyuyla etkileşime geçmekte ve karışmaktadır. Zamanla bu problemi önleme çalışmaları yapılmış olsa da göl kirliliğinin önüne geçilememiştir.

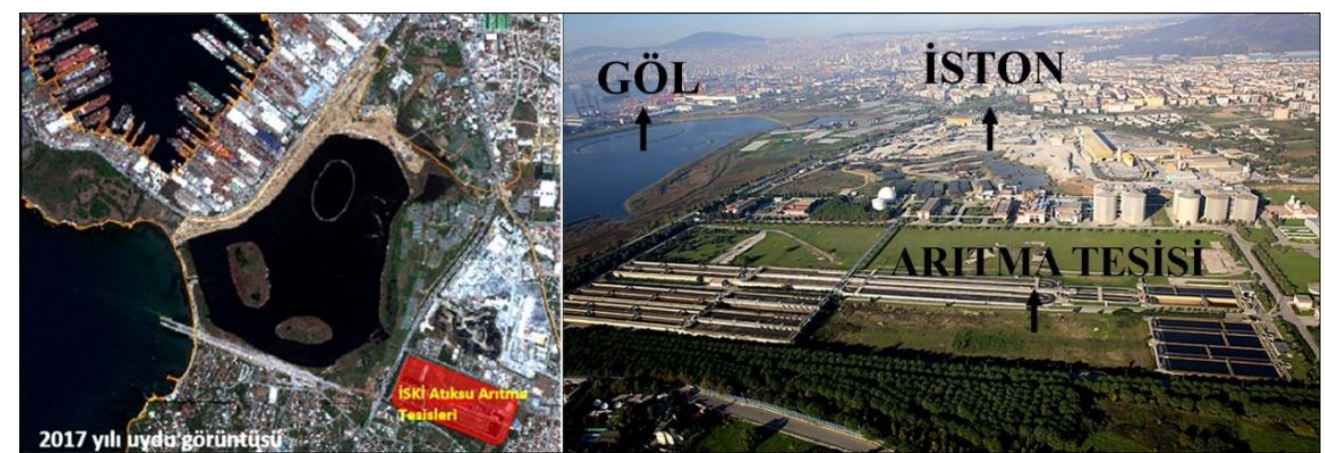

Şekil 9. Kamil Abduş Gölü bitişiğinde İston Fabrikası ve atıksu arıtma tesislerinin konumu (https://www.iski.gov.tr). 


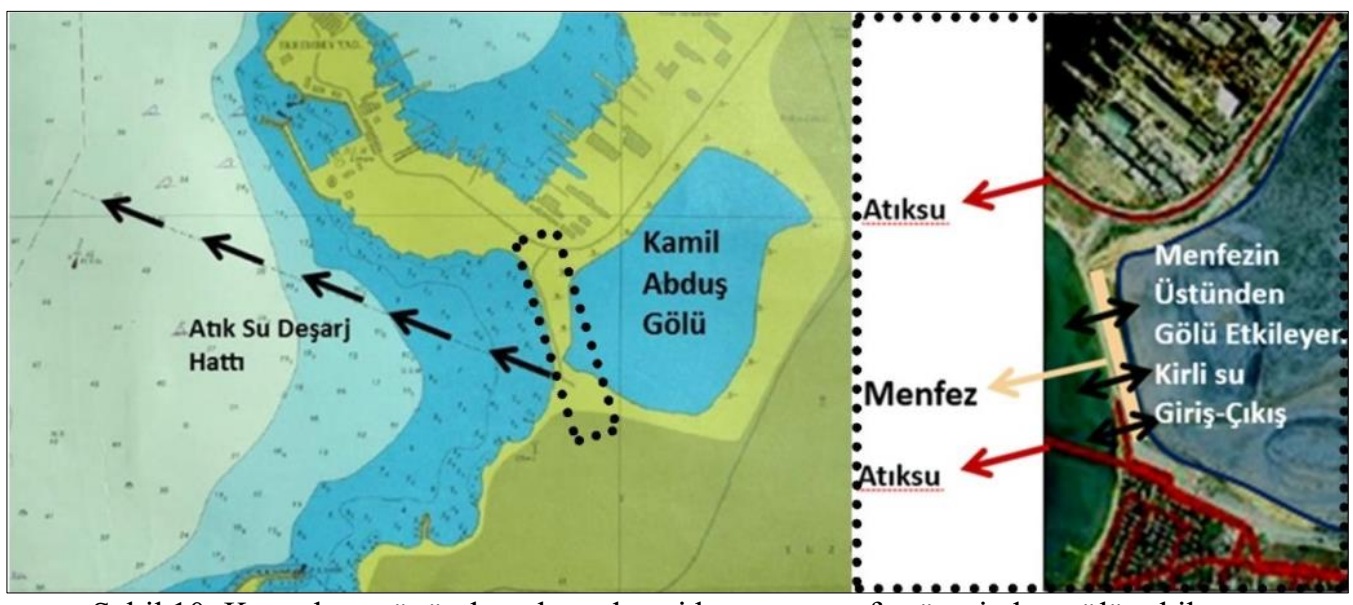

Şekil 10. Kuzeybatı yönünde atık su deşarj hattı ve menfez üzerinden gölü etkileyen kirli su giriş-çıkışı (Bilgili 2008).

\subsection{1/5000 Ölçekli Nazım İmar Planı İlanı ve Gölün Kuruması}

İstanbul Büyükșehir Belediyesi Başkanlığı tarafindan Tuzla Kamil Bey Gölü ve Çevresi Koruma Amaçlı Nazım İmar Planı yapılmış ve 15.03.1999 yılında onaylanmıştır. 15.03.1999 tasdik tarihli Tuzla Kamil Bey Gölü ve Çevresi Koruma Amaçlı Nazım İmar Planında çalışma alanının tamamı koruma alanıdır.

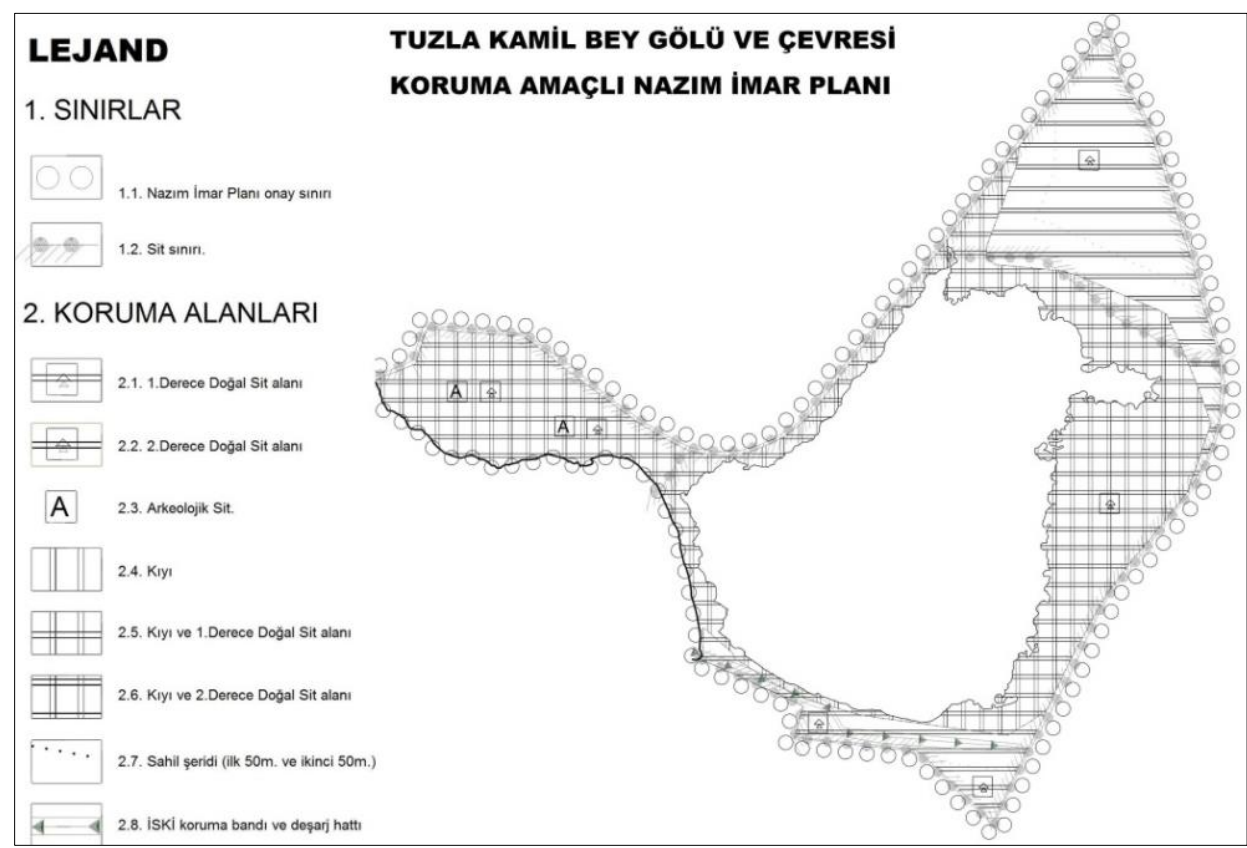

Şekil 11. 15.03.1999 tarihli Tuzla Kamil Bey Gölü ve Çevresi

Koruma Amaçlı Nazım İmar Planı (Tuzla Belediyesi 2017)

Tuzla Kamil Bey Gölü ve Çevresi Koruma Amaçlı Nazım İmar Planına göre Kamil Abduş Gölü ve Sakız Adası 1. Derece Doğal Sit Alanı olup $731561 \mathrm{~m}^{2}$, çevresi ise 2. Derece Doğal Sit Alanı olup 275214 $\mathrm{m}^{2}$ 'dir. Nazım imar planı plan notlarında, kıyı kenar çizgisinden itibaren ilk $50 \mathrm{mt}$. ve ikinci $50 \mathrm{mt}$.'de kıyı kanunu hükümlerinin geçerli olması, uygulama imar planı yapımı sırasında ilgili kurumlardan kurum görüşü alınması gerekliliği, yetkili kurulun Kültür ve Tabiat Varlıkları Koruma Kurulu olduğu ve koruma kararlarına uyulması gerekliliğinin belirtilmesi; planlamada korumaya yönelik olumlu kararların alındığını göstermektedir. Ayrıca nazım imar planı plan notlarına göre 1.derece doğal sit alanı, 2.derece doğal sit alanı ve 1.derece arkeolojik sit alanlarında KTVK Kanunu hükümlerine uyulması ve buna ek olarak kıyı kenar çizgisinden itibaren ilk $50 \mathrm{mt}$. ve ikinci $50 \mathrm{mt}$.'de kıyı kanunu hükümlerine uyulması gerektiği belirtilerek, 1999 yılında sahip olunan yasal düzenlemeler aracılı̆̆ıyla alanın tamamı koruma altına alınmıştır. Bunun yanı sıra göl çevresindeki 2.derece doğal sit alanı günübirlik kullanım fonksiyonu verilerek kısmen yapılaşmaya açılmıştır. Korumaya yönelik önemli bir yasal düzenleme olan 
1/5000 ölçekli nazım imar planı yalnızca yasal statüyü kayda geçiren fiziki bir plan olarak kalmıştır. 1/5000 ölçekli nazım imar planı ile beraber alanın yeniden kazanılması amacıyla düzenlenen hiçbir yaklaşım veya planlama aracı bulunmamaktadır.

\subsection{4-2008 Yılı Yeniden Diriliş Projesi}

Kamil Abduş Gölü'nün kurumasıyla alanın yeniden kazanımı için yerel yönetimler ve kurumlar tarafından araştırma çalışmaları yapılmıştır. Bu çalışmalar sonucunda İstanbul Büyükşehir Belediyesi, Tuzla Belediyesi, Devlet Su İşleri ve İstanbul Çevre Vakfı'nın katılımı ile gölün rehabilitasyonunun sağlanması amacıyla 'Ekolojik Diriliş Projesi' 2004 yılında faaliyete geçirilmiştir. Çalışmalar kapsamında gölün deniz ile bağlantısının sağlayan ancak zamanla denizden gelen kum, toprak ve atıklar sonucu deniz suyu hizasından yükselip gölün denizle bağlantısının kesilmesine sebep olan kıyı kordonundan iki ana kanal açılmış ve kurumuş lagün alanının deniz suyu ile yeniden birleşimi sağlanmıştır.

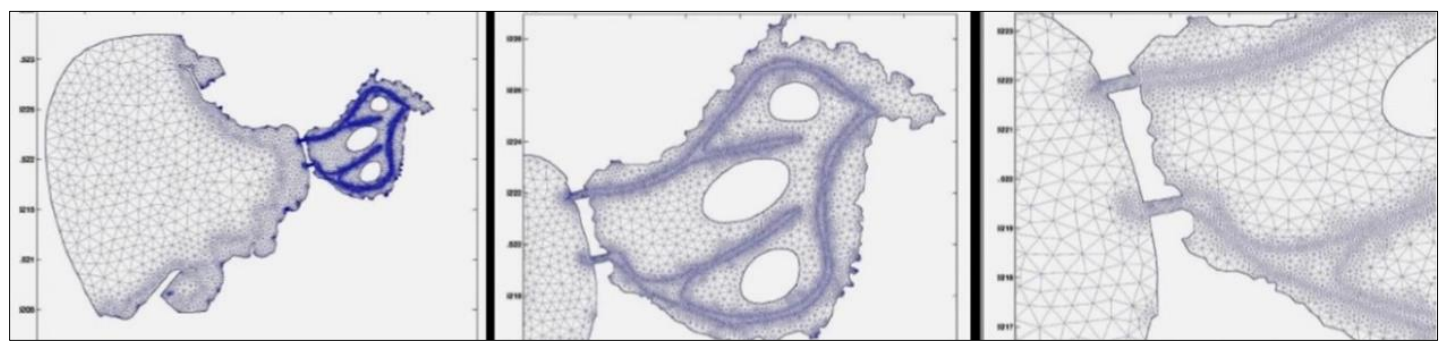

Şekil 12. Yeniden Diriliş Projesi (Tuzla Belediyesi 2017)

Bu projeyle birlikte; Türkiye'nin ve Dünya'nın sayılı lagün göllerinden biri olan ancak 2001 yılında tamamen kuruyan Kamil Abduş Gölü yeniden deniz suyu ile buluşmuştur. Ancak Umur Dere’nin sslah edilememiş ve kurumuş olması sebebiyle tatlı su bağlantısı sağlanamamıştır. Lagün gölünün en önemli birleşeni olan tatlı ve tuzlu su dengesinin tekrar sağlanmaya çalışılması yerine alan sadece tuzlu su ile doldurulmuştur. Bunun yanı sıra gölün içine üç adet yapay ada inşa edilmiştir. Yapay olarak oluşturulmuş adaların alanda hangi fonksiyonla kullanılacağı günümüzde hala bilinmemektedir. Gölün geri kazanılması amacıyla başlatılmış olan ve yapılan öneri projelerinde alana yönelik park alanı tasarımlarına gidilmiş olması dönüşüm ve koruma dengesini sağlama adına atılmış önemli bir adımken alana yapay olarak adacıklar inşa edilmesi doğal yaşamı tahrip etmektedir. Bu durum amacı gölün yeniden kazanılması olan projeyi amacından saptırmıştır.

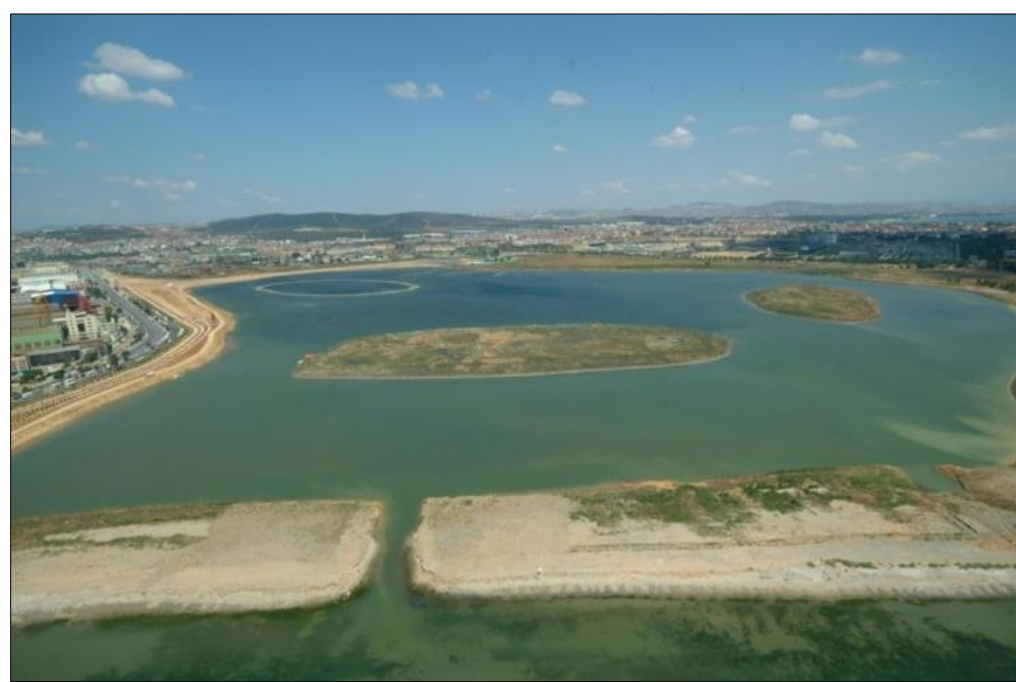

Şekil 13. Yeniden Diriliş Projesi (Tuzla Belediyesi 2017)

\subsection{Yılı Alanın Yenileme Alanı Ilan Edilmesi:}

Kamil Abduş Gölü ve Çevresi, Bakanlar Kurulu tarafından 'Yıpranan Tarihi ve Kültürel Taşınmaz Varlıkların Yenilenerek Korunması ve Yaşatılarak Kullanılması Hakkında Kanun’ kapsamında 27.10.2008 gün ve 2008/14349 sayılı karar ile Yenileme Alanı ilan edilmiştir. Bakanlar Kurulu Kararı ile 
Yenileme alanı ilan edilen bu parseller 5366 sayılı kanun kapsamında, bölgenin gelişimine uygun olarak yeniden inşa edilebilir, bu bölgelerde konut, ticaret, kültür, turizm ve sosyal donatı alanları oluşturulabilir. Bu kapsamda şekil 14'de 27.10.2008 gün ve 2008/14349 sayılı Bakanlar Kurulu Kararı Eki ile yenileme alanına dahil olan parsellerin oluşturduğu 557547.1 m2'lik alan gösterilmiştir. Kamil Abduş Gölünün kuzeyi, doğusu ve güneydoğusunda bulunan bu parsellerin çoğu hisseli şahıs mülkiyetinde olmakla beraber koruma alanının yaklaşık olarak \%40’ını oluşturmaktadır.

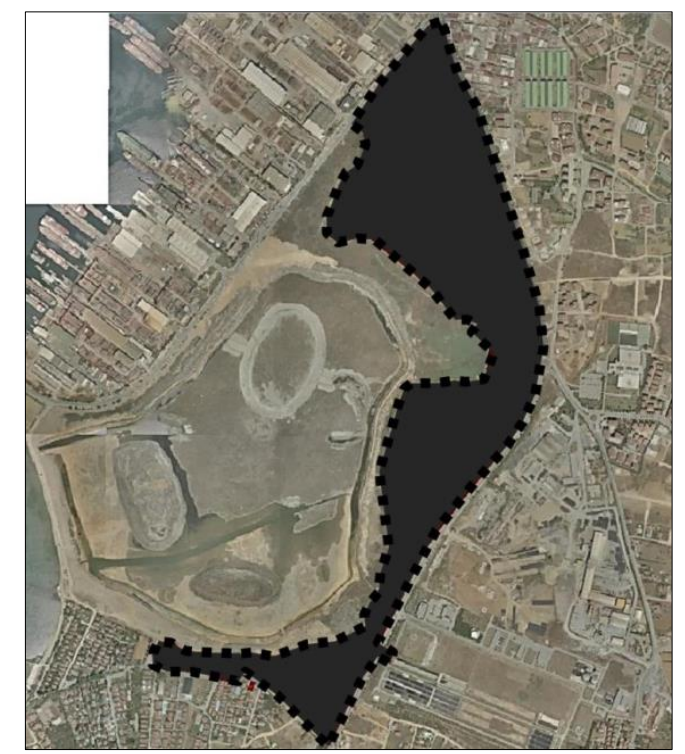

Şekil 14. 27.10.2008 gün ve 2008/14349 sayılı Bakanlar Kurulu Kararı ile açıklanan parseller (Duman 2019, Tuzla Belediyesi 2017)

\section{Sonuçlar}

Bir lagün gölü olarak Tuzla’nın en önemli doğal alanlarından bir olan Kamil Abduş Gölü ve Çevresi doğal sit alanında alınan ve yukarıda aktarılan kararlar değerlendirildiğinde doğal sit statüsünün göl ve çevresindeki doğal özelliklerin korunması ve sürdürülebilirliğinin sağlanması için yetmediğini göstermektedir. Bu süreçteki temel sorunlar ve öneriler aşağıdaki gibidir:

- $\quad$ 1950'li yıllarda göl ve çevresinde tarım fonksiyonlu arazi kullanımının yaygın olması sebebiyle Umur Dere'nin taşkınlarından korunma amacıyla ağzı kuzeye çevrilerek Marmara Denizi'ne verilmesi gölün su ile beslenmesini engellediği gibi tatlı su ile tuzlu suyun buluşmasını kesmiş ve gölün önemli bir özelliği yitirilmiştir. Oysa, su kaynağının yönünün çevrilmesi yerine taşkın riskine karşı derenin akış güzergâhında önlemler alınabilir; dere yatağı veya derenin denize dökülen ağzı genişletilebilirdi. Bu sayede göle tatlı su akışı devam edecek ve kaynak kesilmemiş olacaktı. Bununla birlikte dikkat edilmesi gereken bir diğer önemli nokta tatlı su kaynağının zaman içerisinde kirletilmeden sürekliliğinin sağlanacağı önlemler alınması olmalıydı.

- $\quad$ 1970’li yıllarda bugün Tuzla Tersanelerinin bulunduğu bölge olan Kamil Abduş Gölünün kuzeybatısında kıyı doldurma işlemi ile Ekrem Bey Adası ile Sakız Yarımadası birbirine bağlanmıştır. Oysa, doldurma işlemi yapılmayabilir ve gölün tuzlu su kaynağı olan Marmara Denizi ile bağlantısı koparılmayabilirdi. Bu şekilde lagün gölünün bir doğal birleşeni daha insan eli ile yok edilmesinin önüne geçilebilirdi. Konunun uzmanlarından görüş alınarak doldurulan alanın yeniden kaldırılmasının olabilirliği ve geri dönüşün sağlanabilirliği sorgulanmalı ve mümkün ise acil olarak bu işlemin gerçekleştirilmesi sağlanmalıdır.

- $\quad 1980$ yılına gelindiğinde doldurulan alanda bugün işlevi hala devam eden ve bölgedeki doğal dokuyu bozan en büyük yatırım olan Tersaneler Bölgesi kurulmuştur. Haliç Tersanelerinin göl bitişiğine taşınması Haliç Bölgesini sağlıklaştırma amacıyla atılmış bir adım olsa da göl ve çevresindeki özelliklerin o dönemde de dikkate alınmadığını; devletin yanlış planlama kararları ile karşı karşıya kaldığını göstermektedir. Ayrıca bu durum sanayinin fiziksel ve kimyasal etkilerinin direk olarak göl ve çevresinde görülmesine sebebiyet vermiştir. Zira bir bölgeye sanayi getirmek o bölgede nüfus ve ulaşım yoğunluğunu arttırmakla birlikte bölgesel çevre kirliliği de direk olarak kent içine etki etmektedir. Tersane'nin Tuzla'da kurulma kararı hiçbir planlama verisine dayanmaksızın Bakanlar Kurulu kararı ile getirilen üst otoritenin dayattığı bir karardır. Daha sonra yapılan planlarda plana işlenmesi, yer seçiminin doğrulunu ya da yanlışlığını araştıracak analizler, gelecek yatırımdan bölgenin etkilenme durumu

20 | P a g e

www.iiste.org 
(yoğunluk, ulaşım), doğal sit alanlarının çok yakında olmasının yaratabileceği sorunların görülüp plan ile bu sorunlara çözüm üretebilmenin de yolunu tıkamış durumdadır. Bu nedenle öncelikle tersanenin bu bölgeden desantralizasyonu gereklidir. Böylesi büyük yatırımın desantralizasyonu doğal olarak bir süreç alacaktır. Ancak doğal değerlerden daha fazla kayıp yaşanmaması için bu sürecin başlatılması önemlidir. - $\quad$ 1980’li yıllardaki yapılan müdahaleler ile gölün küçülmesi, faunasının bozulmaya başlaması gibi sonuçlar hala fark edilmemiş olacak ki doğal çevre özelliklerine bakılmaksızın bir diğer sanayi fonksiyonu olan İSTON Fabrikası göl bitişiğine taşınmıştır. Sanayinin bölgeye gelmesi ile göl bitişiğinden yapılan drenajlar ile göl suyunda azalmalar hızla devam etmiştir. ISTON fabrikası da tersane kararı gibi merkezi yönetimin bir kararıdır. İSKI'nin arazisi üzerine kurulmuş, daha sonra plana işlenmiştir. Tersaneye getirilen öneriye benzer şekilde fabrikanın da alandan etaplanarak kaldırılması, doğal sit alanının sürdürülebilirliği için önemli bir karar olacaktır.

- $\quad$ Yapılan tüm müdahalelere rağmen Kamil Abduş Gölü ve Çevresi 1993-1997 yılları arasında 1. ve 2. derece sit alanı ilan edilmiştir. 1. derece doğal sit alanlarında 'yapı yapılamaz' ilkesi bulunmakta, 2.derece sit alanında ise 'kısmen yapılaşma' durumu söz konusudur. Bu olumlu gelişmeye rağmen sit ilanlarından sonra da göl ve çevresine ait doğal özellikler dikkate alınmayarak arıtma tesisleri için İSKİ mülkiyetindeki parsellerde yer seçim kararı alınmıştır. Yine doğal sit alanı ile uyuşmayan bu kararların zaman içinde etaplanarak kaldırılması önerilmektedir.

- $\quad$ Ülkemizde 2863 sayılı Kültür ve Tabiat Varlıklarını Koruma Kanununun amaç, kapsam ve yöntemiyle uyuşmayan 5366 sayılı Yıpranan Tarihi ve Kültürel Varlıkların Yenilenerek Korunması ve Yaşatılarak Kullanılması Kanununun 16.06.2005 yılında yürürlüğe girmesinin ardından 2008 yılında göl ve çevresinin Yenileme Alanı ilan edilmesiyle alanda koruma kuralları kaldırılmış, kentin genel planlama süreci ile uygun olmayacak şekilde yalnızca alan bazında fiziksel yenileme uygulaması ortaya çıkmıştır. $\mathrm{Bu}$ durum alanda mevcut fiziksel sorunları çözmeye yönelik atılmış bir adım olsa da kuşkusuz ileriye yönelik toplumsal, kültürel, sosyal ve doğal sorunların oluşmasına altyapı sağlayacaktır. Oysaki 5366 sayılı kanun amacında doğal sit alanlarını kapsayan bir tanım bulunmamakta ve yenileme alanı ilanı yanlış bir karar olarak değerlendirilmektedir. Doğal sit alanlarının yenileme alanı kapsamından çıkarılmasına yönelik yasal düzenlemelerin yapılması gerekmektedir.

- $\quad$ Alanın doldurulmasına benzer bir diğer müdahale ise 2008 yılında gerçekleştirilen Yeniden Diriliş Projesi ile olmuştur. Bu proje ile göl ve çevresini yeniden canlandırmak amacıyla arayışlara gidilmiş olup tamamen kuruyan gölün yüzey alanı yeniden deniz suyu ile doldurulmuştur. Umur Dere'nin tamamen kuruması sebebiyle bir daha asla eski haline dönemeyecek olan göl deniz suyu ile islah edilmiştir. 1950'li yıllardan itibaren insan eli ile doğaya yapılan müdahalelerden çıkarımlar yapılmayarak bir başka müdahale ile göl içerisinde yapay adacıklar oluşturulmuştur. Oysa 2872 sayılı kanunun 9.maddesinde sulak alanların doldurulması ve kurutulması yolu ile arazi kazanılamayacağı belirtilmiş olup arazi kazanılmasının tespit edilmesi halinde eski haline döndürülmesi zorunluluğu belirtilmiştir. Göl üzerinde oluşturulan yapay adacıklara yenileme kararının ardından herhangi bir kullanım fonksiyonu verilmeden çözüm bulunmalı veya tamamen ortadan kaldırılıp eski haline döndürülmesi sağlanmalıdır. Ayrıca tatlı ve tuzlu su bağlantılarının tamamen ortadan kaldırılması biyolojik varlığını su değişimi ile devam ettiren bir lagün gölü için yapılabilecek en önemli olumsuz müdahaledir. Bu yalnızca lagünün biyolojik özelliklerinin kaybına sebep olmamakta aynı zamanda ağaçlık ve otsu bölgelerde, makilerde, sazlık alanlarda azalmalar da meydana getirmektedir. Bu durum ise gölün yüzeyinin küçülmesinin yanı sıra alanda birçok doğal faunaya zarar vermiş olup kuşların göç güzergâhında bulunan bölgede biyolojik çeşitliliğin de azalmasına sebep olmuştur. Yapay adacıkların kaldırılması da bu bakımdan bir gerekliliktir. Bugün gelinen nokta itibari ile bakıldığında; Göl ve çevresinin kurtarılması için en hızlı şekilde tüm aktörlerle çalıştaylar düzenlenmeli, bilimsel ve akademik çalışmalar ile "Kamil Abduş Gölü ve Çevresi nasıl yeniden canlandırılabilir?” sorusuna yönelik araştırmalar yapılmalı ve kararlar alınarak hızla uygulamaya geçilmelidir.

Son söz; 2001 yılında koruma amacıyla çıkarılan sit alanı ilanları ve Koruma Amaçlı Nazım İmar Planına rağmen Kamil Abduş Gölü tamamen kurumuştur. 2001 yılında gölün tamamen kurumasının ardından 2002 yılında Postane mahallesinde ve göl çevresinde yapılaşma artmaya başlamış, bu nedenle de tarım arazilerinin, alanın batısındaki otsu alanların yerine kaydırıldığı, kuzeydeki sulak alan özellikleri gösteren sazlık alanın parçalandığı görülmektedir. Seraların kurulması ve yapı miktarının artması ile sulak alanlar dolmuş, lagünün kıyı sınırında içe çekilmeler olmuştur. 2002-2003 yıllarında gölün yüzey alanı yaklaşık olarak 862,964 $\mathrm{m}^{2}$ dir. 2002 yılında eskiden lagün özelliğine sahip bir doğal sit alanı olan Kamil Abduş Gölü çevre sağlı̆̆1 açısından bir tehdit haline gelmiş ve bu durum alana müdahale gerekliliğini doğurmuştur. Ancak yapılan müdahaleler kalıcı çözümler üretmediği gibi Alana olumlu katkı da sağlamamıştır. 
Tablo 1. Kamil Abduş Gölü yüzeyinin y1llara göre küçülmesi (Duman 2019)

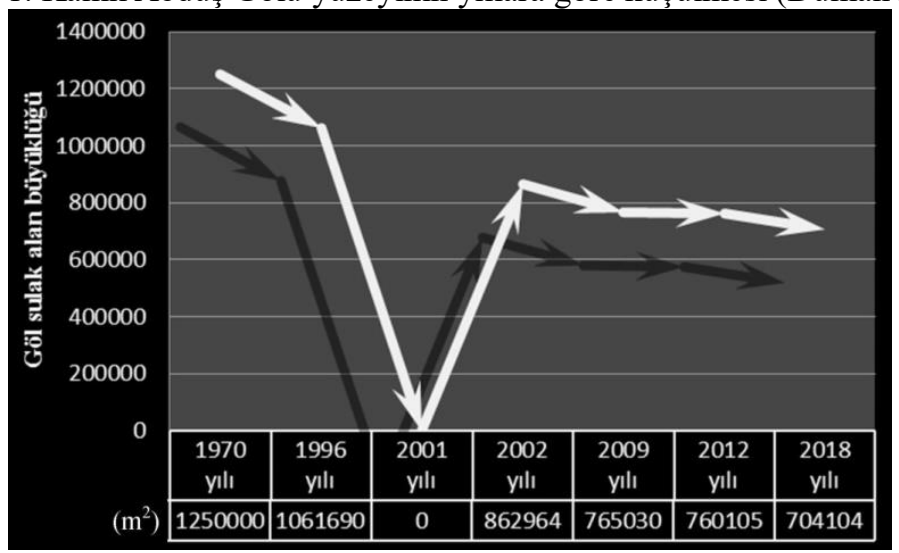

Oysa, Kamil Abduş Gölü ve Çevresinin 2873 sayılı Milli Parklar Kanunu kapsamında bilimsel ve estetik değerlere sahip olması, ulusal ve uluslararası öneme sahip doğal bir alan olması sebebiyle milli park, bitki örtüsü, sahip olduğu yaban hayat ve doğal manzarası, kuşların göç güzergâhında olması, birçok kuş türünü hala barındırıyor olması sebebiyle de halkın dinlenme ve eğlenmesine uygun tabiat parkı olarak düzenlenme potansiyeline sahiptir. Bu kapsamda onaylı imar planları hazırlanarak 6830 sayılı İstimlak Kanununa göre alanda ve çevresinde bulunan tüm özel mülkiyetli parseller kamulaştırmalı özellikle Tersaneler Bölgesi ve Arıtma Tesislerine 1/100000 ve 1/250000 ölçekli Çevre Düzeni Planlarında yeni alanlar önerilmelidir.

IUCN'nin belirlediği koruma kriterleri ile ülkemizdeki koruma kriterlerini eşleştirmeye çalıştığımızda; Mutlak Doğa Koruma Alanlar1- Yabanıl Hayat Alanları I. Koruma Kategorisinin a ve b maddeleridir. Bu alanların denkliği ülkemizdeki Milli Parklar ile örtüşmektedir. Bu kapsamda değerlendirildiğinde Kamil Abduş Gölü ve Çevresinin milli park olarak ilan edilmesi ve bu alanın kuş gözlemciliği, bisiklet yolları, rekreasyon alanları, dinlenme alanları, park alanları, yürüyüş güzergahları, balıkçılık gibi doğal hayata zarar vermeyen fonksiyonlar önerilmesi gölün sürdürülebilir korunması için önemli bir karar olacaktır. Bunun yanı sıra alana yönelik Yönetim Planlarının oluşturulması halkın bilinçli şekilde kullanımını sağlamaya yönelik atılacak gerekli bir adımdır.

AB ye uyum sürecinde Türkiye'nin de taraf olduğu, çevreye ilişkin uluslararası sözleşmeler, deklarasyonlar, protokoller, Türkiye'ye küresel ve bölgesel ölçekte birtakım sorumluluklar yüklemektedir. $\mathrm{Bu}$ sorumluluklar, genellikle deklarasyonlardan kaynaklanan, ulusal hukukta düzenlemeler yapma yükümlülükleri olabileceği gibi, ikili veya çok taraflı sözleşme ve protokollerden kaynaklanan uluslararası hukuk kurallarına uyma ve bu kuralların gereklerini yerine getirme gibi yükümlülükler de olabilmektedir. Flora ve faunanın korunmasına dair Türkiye'nin imzaladığı dört tane önemli uluslararası düzenleme bulunmaktadır. Bunlardan biri de (çalışma alanını da ilgilendiren), özellikle Su Kuşları Yaşama Ortamı Olarak Uluslararası öneme Sahip Sulak Alanlar Hakkında Sözleşme (RAMSAR, 1971)'dir. Sözleşmenin ana amacı doğal kaynakların kullanımını sınırlamaktır. Ancak, Türkiye'nin bu sözleşmelerden kaynaklanan yükümlülüklerini yerine getirmemesi durumunda, bu sözleşmeler de tarife dışı engeller doğurabilecek hükümleri içermektedir. Örneğin, korunması gereken sulak alanlar listesine alınmış bölgelerin yakınlarında, bu bölgelere ve buralarda yaşayan su kuşlarına zarar verebilecek tesisler kurulmamalı, bu gibi bölgelerin yakınlarında kurulacak tesisler hazırlanmalı, kültürel kaynaklar korunmalı, nesli tükenmekte olan yabani hayvan ve bitki türlerinin sözleşme hükümlerine aykırı olacak şekilde doğrudan ticareti ve tüketilmesi engellenmesi gerekmektedir. Bir başka deyişle, imzalanan sözleşmelerin kapsamına giren bölgelerin, ekosistemlerin ve biyolojik çeşitliliğin korunmasını engelleyecek her türlü sınai ve ticari faaliyetten kaçınılmalı, tesisler kurulurken yer seçimine özen gösterilmelidir. Bu açıdan bakıldığında ve değerlendirildiğinde yukarıda da belirtildiği gibi göl çevresindeki büyük ölçekli ve kirlilik yaratan kararların alan dışına alınması aynı zamanda uluslararası bir sorumluluktur.

\section{References}

Anıl, A. (2005) Tuzla'nın mekansal gelişimi, Yüksek Lisans Tezi, İstanbul Üniversitesi, Sosyal Bilimler Enstitüsü, Coğrafya Anabilim Dalı, İstanbul

22 | P a g e

www.iiste.org 
Aydın, A. (1992) Abduş gölü vejetasyonu, İstanbul Üniversitesi Deniz Bilimleri ve Coğrafya Enstitüsü Dergisi, 5

Bilgili, A. (2008) Tuzla Kamil Abdüş gölü’nün bilgisayarda sonlu elemanlar yönetimi ile çevresel akıntı modellemesi için veri toplanması ve bir ağ sistemi geliştirmesi, İstanbul Büyükşehir Belediyesi, Projem İstanbul Araştırma Projesi Raporu, İ.T.Ü. Denizcilik Fakültesi, İstanbul

Ceran, Y. (2007) Türkiye'nin sulakalan mevzuat1, H. Özbek içinde, Sulakalan yönetim planlaması rehberi Ankara: Doğa Koruma ve Milli Parklar Genel Müdürlüğü Kuş Araştırmaları Derneği, Ankara, 90

Doğaner, S. (1993) İstanbul'da gemi inşa sanayi, Türk Coğrafya Dergisi, (28), İstanbul, 65-114

Doğaner S. (2000) Kıyı oklarının doğal varlıklar olarak korunması, Türk Coğrafya Dergisi, (8), İstanbul, 10

Dudley N. (2008) (Ed.), Guidelines for applying protected area management categories, Gland, Switzerland: IUCN, 86, 2008

Duman G.G. (2019), Kamil Abduş Gölü doğal sit alanı ve çevresinde koruma ve yenileme çelişkisinin incelenmesi, Yüksek Lisans Tezi, Yıldız Teknik Üniversitesi, Fen Bilimleri Enstitüsü, Şehir ve Bölge Planlama Anabilim Dalı, Danışman : Örnek Özden, E.

Kültür Varlıklarını Koruma Yüksek Kurulu, 19.06.2007 gün ve 728 No'lu İlke Kararı

Mutluay, G. Ü. (2015), Sürdürülebilir kentsel gelişme ve doğa koruma çerçevesinde İstanbulBeykoz örnek alanının incelenmesi, Yüksek Lisans Tezi, Yıldız Teknik Üniversitesi, Fen Bilimleri Enstitüsü, Danışman : Örnek Özden E.

Nagel, P. (2003), Die schutzgebietskatagorien. Tiergeographie und naturschutz, WS 02/03, http://www.nlu.unibas.ch/PDF/ IUCN.pdf

Ortaçeşme, V. Karagüzel, O. Atik, M. (1998), Dünyada ve Türkiye'de doğa koruma politikalarının gelişimi, cumhuriyetimizin 75. yılında ormancılı̆̆ımız sempozyumu, Bildiriler Kitabı, İstanbul Üniversitesi, Orman Fakültesi, İstanbul, 649-666

Özdemir, M. (2011), Tuzla Tarihi, Tuzla Belediyesi kültür hizmeti, İstanbul, 392, 2011

Özkaya, M. (1993), Bütün özellikleri ile Tuzla tanıtım rehberi, İstanbul, 1993

Soyhan, C. (1996), Sanat Tarihi Araştırmaları Dergisi, İstanbul, 25

TC. Resmi Gazete "Sulak Alanların Korunması Yönetmeliğï”, R.G: 04.04.2014 tarih ve 2896 say1, http://www.resmigazete.gov.tr/ , Erişim Tarihi:07.03.2017

T.C Tarım ve Orman Bakanlığı ( eski T.C. Orman ve Su İşleri Bakanlığı). http://www.ormansu.gov.tr. Erişim Tarihi: 01.12.2018

Tuncay, E. H. (2016), İstanbul İli, Tuzla İlçesi, Tuzla Kamil Abduş Gölü Çevresi Düzenleme Projesi, 1.Derece Arkeolojik Sit Alanı "Sakız Adası", peyzaj ön projesi, peyzaj uygulama raporu, 8.Ulusal Peyzaj Mimarlığı Ödülleri, Analiz ve Planlama 1.Ödülü, İstanbul, 17

Tuzla Belediye Başkanlığı, Plan ve Proje Müdürlüğü Arşivi (2017), İstanbul 
Tuzla Çevre Gönüllüleri (1991), Tuzla Balık Gölü’nün ve yöresinin rehabilitasyonu, ön rapor, İstanbul, 3-8

Türk, A. (1995), Kentsel koruma yaklaşımlarında kentsel kimliğin korunması, Isparta örneği, Yüksek Lisans Tezi, İstanbul Teknik Üniversitesi, Fen Bilimleri Enstitüsü, İstanbul, 130

Türkiye Barolar Birliği (TBB) Yayını (2014), Uluslararası çevre koruma sözleşmeleri, 247, Ankara

Yalçıner, E. Ö. (2005), İmar planları yerine sürdürülebilir kent planları, Journal of the Faculty of Engineering and Architecture of Gazi University, 18(3), 529-544

https://yandex.com.tr/harita/, Erişim tarihi: 06.08.2018

https://sehirharitasi.ibb.gov.tr/, Erişim tarihi:06.08.2019

İstanbul Su ve Kanalizasyon İdaresi Genel Müdürlüğü, https://www.iski.gov.tr/web/trTR/kurumsal/iski-hakkinda/aritma-tesisleri/atiksu-aritma-tesisleri/tuzla-atiksu-aritma-tesisi, Erişim Tarihi: 24.06.2016 